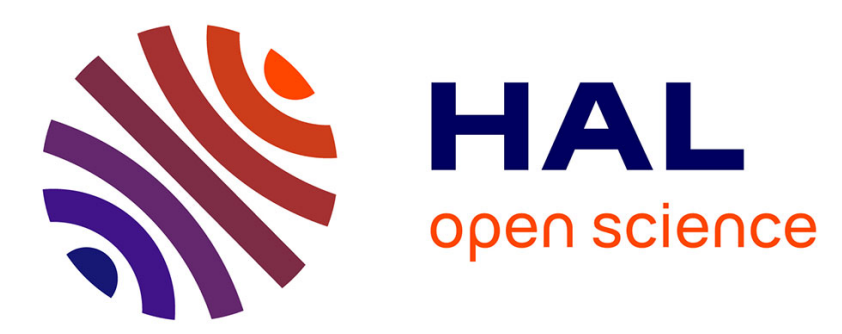

\title{
University Technology Transfer offices: the search for identity to build legimacy
}

Conor O'Kane, Vincent Mangematin, Will Geoghegan, Ciara Fitzgerald

\section{To cite this version:}

Conor O'Kane, Vincent Mangematin, Will Geoghegan, Ciara Fitzgerald. University Technology Transfer offices: the search for identity to build legimacy. Research Policy, 2015, 44 (2), pp.421-437. 10.1016/j.respol.2014.08.003 . hal-01072998

\section{HAL Id: hal-01072998 \\ http://hal.grenoble-em.com/hal-01072998}

Submitted on 8 Oct 2014

HAL is a multi-disciplinary open access archive for the deposit and dissemination of scientific research documents, whether they are published or not. The documents may come from teaching and research institutions in France or abroad, or from public or private research centers.
L'archive ouverte pluridisciplinaire HAL, est destinée au dépôt et à la diffusion de documents scientifiques de niveau recherche, publiés ou non, émanant des établissements d'enseignement et de recherche français ou étrangers, des laboratoires publics ou privés. 


\title{
UNIVERSITY TECHNOLOGY TRANSFER OFFICES: THE SEARCH FOR IDENTITY TO BUILD LEGITIMACY
}

\author{
Conor O'Kane*
}

Department of Management

University of Otago

Dunedin

New Zealand

conor.okane@otago.ac.nz

$\mathrm{Ph}(0064) 34798121$

Vincent Mangematin

Grenoble Ecole de Management

France

vincent.mangematin@grenoble-em.com

Will Geoghegan

Whitman School of Management

Syracuse University

New York

wjgeoghe@syr.edu

Ciara Fitzgerald

Financial Services Innovation Centre

University College Cork

Cork

Ireland

CFitzgerald@ucc.ie

* Corresponding author 


\begin{abstract}
Technology transfer offices (TTOs) are of strategic importance to universities committed to the commercialization of academic knowledge. Within the university, TTOs' relationship with academics and management is single agent-multiple principal. When two principals exist in an agency relationship, conflicting expectations can naturally arise. We explore how TTOs build legitimacy by shaping identity with university academics and management. In undertaking this research we draw on 63 interviews with TTO executives across 22 universities in the Ireland, New Zealand and the United States. We find that TTOs use identity-conformance and identity-manipulation to shape a dual identity, one scientific and the other business, with academics and management respectively. We show how this combination of identity strategies is ineffective for legitimizing the TTO. We propose that TTOs' identity shaping strategies are incomplete and need to incorporate a wholly distinctive identity to complement and reinforce preliminary legitimacy claims made through conformance and manipulation. We discuss the potential implications of these findings for scholars, TTO executives and university management.
\end{abstract}

Keywords: technology transfer office; legitimacy; identity; strategy; 


\section{Introduction}

University TTOs are enigmatic actors in the academic entrepreneurship arena. Today TTOs' identity is loosely regarded as one of "boundary spanner" or "broker" between academia and industry (Phan and Siegel, 2006; Powers and McDougall, 2005; Rothaermel et al., 2007). TTOs help academics to understand the needs of industry and to access critical resources, expertise and support in the commercialization process (Clarysse and Moray, 2004; Colombo and Delmastro, 2002; Markman et al., 2005; Siegel et al., 2003).

How exactly TTOs go about legitimizing their role and shaping their identity within the university, however, remains unclear. Theory suggests that when shaping their identity, TTOs should capture what elements are central, distinctive, and enduring about their office (Albert and Whetten, 1985; Pratt and Foreman, 2000). They need to specify who they are, what they do and why they are successful (Livengood and Reger, 2010). However, with TTOs operating as a dual agent for university academics and management, this is not a straight forward task. When two principals exist in an agency relationship, conflicting expectations naturally arise. For TTOs, this conflict results in efforts to balance academic and commercial forces when shaping their identity. In order to improve our understanding of how TTOs manage this challenge we explore how TTOs build legitimacy by shaping identity with university academics and management.

Legitimacy is defined as "a generalized perception or assumption that the actions of an entity are desirable, proper, or appropriate within some socially constructed system of norms, values, beliefs, and definitions" (Suchman, 1995, p. 574). It is acknowledged that an organization's identity work helps to build legitimacy (Brown and Toyoki, 2013; Navis and Glynn, 2011), particularly when attempting to shape identity with multiple stakeholders (Chermak and Weiss, 2005; Sillince and Brown, 2009). Establishing legitimacy within the university is fundamentally important for TTOs. Once legitimate, TTOs may have greater 
access to resources (Ashforth and Gibbs, 1990; Pfeffer and Salancik, 1978; Zimmerman and Zeitz, 2002) and encounter less contestation when promoting commercialization activities and practices within the university (Colyvas and Jonsson, 2011; Jepperson, 1991). In contrast, a failure to establish legitimacy may result in disengagement, the withdrawal of resources, and claims that its role is redundant. Of particular relevance to TTOs is Bishop Smith's (2011) suggestion that organizations must concentrate on building legitimacy before ever expecting to be profitable.

However, when building legitimacy within the university, TTOs must manage the challenging dilemma of sameness and uniqueness in their identities (Navis and Glynn, 2010). Specifically, akin to "optimal distinctiveness" (Brewer, 1991), TTOs must attempt to differentiate their office from the university environment so that they are "legitimately distinct" (Navis and Glynn, 2011), but also be careful that they are not so distinct that their office appears irrelevant to university academics and management. To address this research topic, we develop two legitimacy-building identity strategies. TTOs adjust their identity and promote sameness and homogeneousness with existing dominant norms and expectations within the university through identity-conformance. TTOs proactively sense what they believe is required in the university and then shape an identity that captures both their ability to meet these expectations and the unique or distinctive value of their role through identitymanipulation. Predicting a search for legitimacy through optimal distinctiveness, we explore to what extent TTOs use identity-conformance and identity-manipulation when shaping their identity with university academics and management.

The contributions from our study are as follows. First, when building legitimacy with two principals, we propose that shaping and blending two contradictory identities blurs identity and ultimately diminishes legitimacy with both principals. This is apparent in how TTOs in our study shape a dual identity, one scientific and the other business, with university 
academics and management respectively. We explain how this approach is proving ineffective for legitimizing the TTO. Second, we suggest that misinterpreting social cues, or the expectations and requirements of evaluating audiences, can lead to misaligned identity shaping strategies that also result in legitimacy discounts. Again, this is evident in the manner by which TTOs, despite acknowledging the value placed on commercial and business development skills by the academics, choose to prioritize and shape a scientific identity for this principal. Third, and most importantly, we propose that in order to build legitimacy within the university TTO executives need to shift their attention towards shaping a distinctive identity. Although we find that TTOs do conform to dominant academic norms (identity-conformance) and meet anticipated requirements from management (identitymanipulation); we suggest that these represent preliminary efforts by them to become a part of a shared university identity. However, because legitimacy is as dependent on being different as it is on being the same (Deephouse, 1999), we argue that TTOs' search for legitimacy, as illustrated in our findings, is incomplete. Our final propositions, therefore, encourage TTOs to fully extend their use of identity-manipulation in order to individuate their identity. In shaping their own distinctive identity, we suggest that TTOs could complement and reinforce preliminary legitimacy claims made through identity-conformance and (partial) identity-manipulation.

The remainder of this paper is organized as follows. Section 2 presents a brief background on the relationship of the TTO with its two key principals in the university environment. Section 3 outlines the theoretical grounding underpinning the study's research focus. In sections 4 and 5 we detail the study's methodology and research findings respectively. Section 6 discusses the implications of these findings and presents a number of propositions. Finally, Section 7 brings the paper to a close with some concluding points and an overview of some limitations and avenues for future research. 


\section{Background - TTOs and the multi-stakeholder university environment}

TTOs have two principal stakeholders within the university - academics and management. ${ }^{1}$ Universities have traditionally focused on basic research (Nelson, 1959) which is characterized by scientific autonomy (Bush, 1945; Nelson, 2004) and guiding norms of skepticism, universalism, communism and disinterestedness (Merton, 1973). University academics who pursue a career in these institutions are, therefore, typically motivated by originality and discovery, and are rewarded through open dissemination, citation, professional awards (Dasgupta and David, 1994; Merton, 1973), scientific priority (Merton, 1957) and recognition (Latour and Woolgar, 1979). Commercially-oriented research is not mutually exclusive from basic research, however (Daraio et al., 2010; Jensen et al., 2003; Stokes, 1997). Outcomes that eventually result in "higher standards of living" (Bush, 1945) must often be articulated to justify scientific exercises. Nevertheless, with a greater focus on market needs, knowledge exclusion, market share and economic returns, proprietary science and research commercialization can be misaligned with the research norms and reward structures of university academics (Haeussler and Colyvas, 2011; Nelson 1959). Commercial research, for example, can increase the level of secrecy in science (Campbell et al., 2000), delay disclosure and publication (Blumenthal et al., 1996; Huang and Murray, 2009; Thursby and Thursby, 2003) and reduce technological breakthroughs (Jung and Lee, 2014) and the accumulation of public knowledge (Toole and Czarnitzki, 2010). The conflict between these trends and those norms that traditionally dominate a "scientific identity" means that university academics do not uniformly accept TTOs as legitimate entities.

\footnotetext{
${ }^{1}$ For our study university academics are those personnel who undertake academic research and university management are those personnel occupying positions of formal administration in the university structure. University academics incorporate such titles as professor, associate professor, assistant professor, lecturer, scientist, research leader, research director, principal investigator, or equivalent. University management incorporates such titles as the Council, Board of Trustees, Vice President (VP), Vice Chancellor (VC), Executive Vice President, Deputy Vice-Chancellor (DVC), Provost, Pro Vice Chancellor (PVC), Dean, Head of Department (HOD), Department Chair and equivalent personnel. Whilst neither principal can of course be definitively aligned with academic or commercial science, the dominant tasks and professional demands associated with both principals would suggest that management may be more supportive of the TTO.
} 
University management is more likely to see TTO effectiveness as an issue of strategic importance. Universities are pivotal actors in increasingly knowledge-intensive economies and societies (Martin, 2012). Intellectual capital, emerging from public-private research projects and technology transfer activities, contributes to industry innovation, economic growth and social development in knowledge based economies (Etzkowitz, 2003; Feller 1990; Mangematin et al., 2014; Rothaermel et al., 2007; Sörlin, 2007). University management, therefore, has an interest in ensuring their TTOs contribute to national competitiveness through the commercialization of university research (Bozeman, 2000; Mowery and Ziedonis, 2002). University contributions to local, regional and national communities show that public funding is worthwhile and provides a return to society. Furthermore, with an increasingly competitive and constrained public funding environment, management of both public and private universities realize that an efficient TTO can help generate earnings (e.g., licensing income) that can protect existing research activities and help pursue future research breakthroughs (Bozeman, 2000). Proficiency in technology transfer can enhance the reputation and prestige of the university, thus helping to recruit and retain leading researchers and increase student intake (Etzkowitz and Leydesdorff, 2000; Markman et al., 2009). TTOs are, therefore, likely to emphasize their commercial potential on behalf of the university through the shaping of a "business identity".

It is apparent from this overview that university TTOs operate in a pluralistic context, characterized by competing strategic demands and potentially divergent stakeholder goals (Denis et al., 2007; Glynn et al., 2000; Van Gestel and Hillebrand, 2011). Academic capitalism (Slaughter and Leslie, 1997), the "triple helix" (Etzkowitz and Leydesdorff, 1997) and the evolving entrepreneurial university (Etzkowitz, 1983) continue to blur the boundaries between science and business. When institutional logics overlap in this manner, significant strains are encountered by those structures (e.g., TTOs) caught within the shared boundaries 
as understandings of behaviors, responsibilities and meaning become unclear (Murray, 2010). This context complicates TTO efforts to build legitimacy and shape identity with university academics and management. We next explain the theoretical grounding underpinning our focus on this challenge for TTOs. Figure 1 presents a framework that summarizes this research focus.

\section{INSERT FIGURE 1}

\section{Theoretical development}

A TTO's relationship with university academics and management is one of principal-agent. According to agency theory, a principal hires an agent with specialized knowledge and skills to undertake work on their behalf (Eisenhardt, 1989; Gomez-Mejia and Balkin, 1992; Jensen and Meckling, 1976). TTOs are agents of commercialization in universities because academics and management lack expertise and knowledge of the processes and language of proprietary science. TTOs operate as a dual agent who must "balance the objectives of the university, which owns the inventions, and the faculty, who create them" (Jensen et al., 2003, p. 1272). Specifically, TTOs' relationship with university academics and management is one of single agent-multiple principal.

Little is known about how TTOs build legitimacy in this (multi) stakeholder relationship. Theory informs us that (normative) legitimacy is derived from evaluations by key audiences (Bitektine, 2011; Dowling and Pfeffer, 1975). This centres on evaluations by university academics and management and whether or not they accept the TTO as appropriate (Hunt and Aldrich, 1996; Scott, 1995). Endorsements from these stakeholders are crucial for the legitimacy of the TTO (Drori et al., 2009; Starr and MacMillan, 1990). The types of legitimacy that can materialize from these evaluations include pragmatic and moral legitimacy. Pragmatic legitimacy is determined by the extent to which university academics' 
and managements' (principal) own interests and priorities will be satisfied by the TTOs' (agent) commercialization activities. Suchman (1995, p. 578) refers to this as the "selfinterested calculations of an organization's most immediate audiences." This means academics will evaluate how engaging with the TTO can improve their career progression or influence the impact and reach of their research, and management will evaluate how commercialization activities improve the university's ranking, reputation, research income and levels of external engagement. Closely related to pragmatic legitimacy, and in line with the traditional norms of universities around knowledge accumulation, full disclosure, universalism, communism and disinterestedness (Dasgupta and David, 1994; Merton, 1973), is moral legitimacy. Moral legitimacy is less about university academics' and managements' own interests than about whether the TTO's role and commercialization activities are deemed "the right thing to do" (Suchman, 1995), and can result in the work of academics and universities benefiting a wider and more diverse group of actors in society (Bitektine, 2011). In developing the theoretical framing for how TTOs build legitimacy, it is important to include a review of existing literature in the area of TTO legitimacy.

\subsection{TTO legitimacy}

A notable contribution on the subject of TTO legitimacy is provided in Jain and George's (2007) study of the Wisconsin Alumni Research Foundation's (WARF) influential role in the emergence of human embryonic stem cell technology. Drawing attention to the dual responsibilities TTO executives have towards universities and society, the authors characterize TTOs as proactive entrepreneurs that build legitimacy for novel technologies. In their study, however, Jain et al. (2007) focused on how TTOs shape institutional environments (rules, norms and understandings) that reduce uncertainty around novel innovations, rather than the ambiguity inherent in their own role within the university. With 
regard to the latter, Colyvas and Powell (2006) used archival sources from a forerunning TTO to track how disparate technology transfer practices and contributing entities gradually evolved to become consolidated, normalized and legitimate at Stanford.

Additionally, scholars have directed a substantial amount of attention at the evolution and legitimization of academic entrepreneurship activities within universities more generally (Colyvas, 2007; Colyvas and Powell, 2007). They have examined the motivations of academics (D’Este and Perkmann, 2011), key social environment determinants (Bercovitz and Feldman, 2008; Haeussler and Colyvas, 2011; Kenney and Goe, 2004; Stuart and Ding, 2006; Tartari et al., 2014), as well as the coping strategies and role identity modifications (Jain et al., 2009; Lam 2010) underpinning their engagement in academic entrepreneurship. Scholars have repeatedly emphasized the importance for management of providing attractive rewards and incentives for both faculty who develop new technologies (i.e., favorable royalty distribution schemes that sufficiently incorporate faculty interests), and compensation for the TTO staff member(s) who help process resulting commercial outcomes (e.g., patents, license revenues or spinoffs) (Friedman and Silberman, 2003; Link et al., 2005). University management can also encourage academic-TTO engagement by promoting an entrepreneurial culture with transparent regulations around IP (Debackere and Veugelers, 2005; Tartari et al., 2012) and placing a higher value on patenting, licensing, and start-up formation in promotion and tenure decisions (Ambos et al., 2008; Goldfarb and Henrekson, 2003; Link et al., 2007).

To the best of our knowledge, little if any in-depth research attention within these conversations has been directed at how TTOs build legitimacy by shaping identity with university academics and management. We find this surprising given that TTOs are such pivotal intermediaries in the entrepreneurial university. Evidence that draws attention to the questionable effectiveness and value of TTOs would indicate that this subject may benefit from closer empirical inquiry. More specifically, despite their ubiquity scholars report how 
TTOs have only marginal direct effects in stimulating academic entrepreneurship (Muscio, 2010) and that their role is secondary to the entrepreneurial capacity of academics (Clarysse et al., 2011). It is also now accepted that many academics deliberately bypass the TTO and independently commercialize or use their innovations without going down formal university channels via the TTO (Aldridge and Audretsch, 2011; Bodas-Freitas et al., 2013; GöktepeHultén, 2008; Link et al., 2007; Lockett and Wright, 2005; Markman et al., 2008, Shane, 2004; Siegel et al., 2003, 2004; Thune and Gulbrandsen, 2011). Furthermore, TTOs are viewed as being deficient in business related skills (Chapple et al., 2005; Decter et al., 2007; Mustar et al., 2006; O’Shea et al., 2005; Swamidass and Vulasa, 2009). The apparent dissatisfaction among many academics with their TTO is likely to be coupled with frustrations among management that the university is not fully exploiting the revenue potential of its research activities and intellectual property. Therefore, we believe that an examination of how TTOs legitimize their role with academics and management is overdue. In the sections that follow, we continue to draw on legitimacy and identity literatures to develop a theoretical understanding of how TTOs might build legitimacy by shaping identity.

\subsection{Identity and TTO legitimacy-building}

The strategic view of legitimacy proposes that legitimacy can be actively managed. The legitimacy-seeking entity (the TTO) will "put forward the impression that its identity is such that it provides what is needed or desired and will be successful in the business domain in which it purports to operate" (Zimmerman and Zeitz, 2002, p. 420). Although scholars have identified several legitimacy-building strategies, these can be reduced to two dominant categories. Conformance strategies (Dowling and Pfeffer, 1975; Suchman, 1995; Zimmerman and Zeitz, 2002), the least strategic approach, would involve internal adjustments of the TTO's structures and practices to comply with the values, rules, and norms of university 
academics and management. Oliver (1991), for instance, referred to acquiescence, compromize and avoidance when discussing legitimacy through conformance. Manipulation strategies (Dowling and Pfeffer, 1975; Zimmerman and Zeitz, 2002) would involve proactive interventions to achieve consistency, or at least some degree of support, between the TTO and the values, rules and norms of university academics and management (Suchman, 1995). It involves the "purposeful and opportunistic attempt to co-opt, influence or control institutional pressures and evaluations" (Oliver, 1991, p. 157).

One way in which TTOs can utilize these strategies to build legitimacy is by shaping identity, as described by Elsbach and Kramer (1996, p. 470), “(when) organizational members perceive that their organization's identity is threatened, they (will) try to protect both personal and external perceptions." Identity theory explains how individuals in the workplace both shape and reinforce their identity through their actions and behaviors (Burke, 1980; Pratt, 2000; Stryker and Burke, 2000). Drawing on the two dominant strategies introduced above, we develop two legitimacy-building identity strategies. Legitimacybuilding through identity-conformance would involve TTOs deliberately adjusting their identity to ensure close alignment with what they regard as the dominant values and norms of university academics and management. In contrast, legitimacy-building through identitymanipulation would see TTOs attempt to proactively control or influence how university academics and management view their office in order to evoke positive evaluations. TTOs will concentrate on detecting what behaviors they regard as needed and valued from their role by university academics and management, and then shape an identity consistent with these behaviors (Ashforth and Humphrey, 1993). A number of legitimacy strategies that TTOs could utilize for the purpose of identity manipulation have been reported in the literature. These include the use of persuasion (Hambrick and Chen, 2008), symbolic management conveying personal credibility, professional organizing, organizational achievement and 
stakeholder relationship quality (Zott and Huy, 2007), impression management (Ashforth and Gibbs, 1990; Gardner and Avolio, 1998), storytelling (Lounsbury and Glynn, 2001), lobbying (Hinings and Greenwood, 1988) and rhetoric (Sillince and Brown, 2009; Suddaby and Greenwood, 2005). Thus, in sum, TTOs react and promote sameness and homogeneousness with existing dominant norms and expectations within the university through identityconformance. On the other hand, TTOs proactively sense what they believe is required in the university and then shape an identity that captures both their ability to meet these expectations and the unique or distinctive value of their role through identity-manipulation.

However as alluded to earlier, TTOs' efforts to build legitimacy and shape identity will be complicated by the overlapping logics of commercialization and academia and, as a consequence, the multiple, sometimes competing demands inherent in their multi-principal relationship. It is unlikely that one strategy or identity will be sufficient to legitimize the TTO with both academics and management. Therefore, to bring our theoretical framing to a close, we look at how multiple identities might be managed by the TTO.

\section{Managing multiple identities}

It is commonly accepted that organizations hold, and purposefully manage, multiple identities (Albert and Adams, 2002; Pratt and Foreman, 2000; Vora and Kostova, 2007). As is the case for TTOs balancing economic and academic priorities, multiple identities are often necessitated when dealing with overlapping boundaries (Zuckerman, 1999) and multiple stakeholders (Brickson, 2005). However, multiple identities can conflict and cause uncertainty within the organization (Pratt and Rafaeli, 1997), even resulting in legitimacy discounts from the organization's interested stakeholders (Dutton and Dukerich, 1991; Zuckerman, 1999). Such side effects led Pratt and Foreman (2000) to emphasize how important it is for organizations (e.g., TTOs) with multiple identities (e.g., "scientific" and 
"business") to manage them carefully in order to avail of the potential benefits they can bring. Among the benefits that multiple identities can provide is the ability to deal with the "ambiguity" (Eisenberg, 1984) that arises when logics overlap and stakeholder expectations diverge. Specifically, (multi) identity can be a critical legitimacy-enabling asset as it allows organizations (e.g., TTOs) to be more responsive and resilient to stakeholders (academics and management) who have a variety of needs (e.g., academic and commercial) and expectations (Albert and Whetten, 1985; Navis and Glynn, 2011). In an examination of police websites, for example, Sillince and Brown (2009) argued that the legitimacy of an organization subject to conflicting demands from sceptical stakeholders can be supported by multiple identities, and therefore, they should avoid working to resolve these competing identities.

Nevertheless, when building legitimacy, managing multiple identities is a complex task. The salience of a particular identity at a given time relies largely on its fit or sense of membership with the situational context (Ashforth and Johnson, 2001; Dutton et al., 1994; Turner, 1987). As pointed out by Kistruck et al. (2013), this situational context is a function of both the degree to which an identity is desirable or satisfies a need for self-esteem and selfworth (Ashforth and Johnson, 2001; George and Chattopadhyay, 2005), and the external social cues (i.e., interactions with academics and management) that take place in this environment (Ashforth et al., 2008; Gioia et al., 2000). In particular, organizations need to address the challenging dilemma of sameness and uniqueness in their identities (Navis and Glynn, 2010). Theory informs us that, when confronted with multiple stakeholders, solely concentrating on 'fitting in' and being the same is insufficient to build legitimacy. For example, in an examination of the return on investment and capital flows in the global hedge fund industry, Smith (2011) found that non-conformance to certain identity-based logics is not only acceptable to key stakeholders, but even rewarded. Likewise, in an update on Albert and Whetten's (1985) initial identity proposal, Whetten (2006) emphasizes that identity 
equates to a subjective sense of uniqueness that explains how one is different from all others. Avoiding a one-dimensional approach to shaping identity is equally important in contexts where boundaries overlap. Based on an in-depth study of an exclusive license agreement between Harvard and DuPont, Murray (2010, p. 346) argued that, rather than managing the tensions that arise from the overlapping logics of science and business through the accepted wisdom of collapse, blending or coexistence, we should build on the tensions to strengthen the distinction between the two boundaries, resulting in what she refers to as a "productive tension”.

Therefore, the challenge for TTOs building legitimacy through identity appears to be one of achieving "optimal distinctiveness" (Brewer, 1991). Optimal distinctiveness, or strategic balance (McNamara et al., 2003), refers to an organization's ability to sufficiently differentiate itself from its environment so that it is respected as being unique, but not so unique that it is completely disenfranchised from the environment. This concept has direct ramifications for an organization's legitimacy. For example, Deephouse (1999) argued that "organizations should be as different as legitimately possible." Likewise, in an examination of investor evaluations on new venture plausibility, Navis and Glynn (2011) explained how identities receive favourable judgements when they are "legitimately distinctive". These types of identities contain legitimacy claims that align the organization with stakeholder expectations and institutionalized norms, as well as claims of distinctiveness that clearly deviate the organization from these same forces.

In sum, the purpose of this study then is to explore how TTOs build legitimacy by shaping identity within the university. More specifically, predicting a search for legitimacy through optimal distinctiveness, we wish to explore to what extent TTOs use identityconformance and identity-manipulation when shaping their identity with university academics and management. 


\section{Methodology}

We undertook an in-depth exploratory approach to research how TTOs build legitimacy by shaping identity with academics and management. This approach was deemed most appropriate given the range of subjective realities that could exist when examining TTO executives' identity shaping strategies within the university environment. Given the disparate structural arrangements of universities' technology transfer entities, it should be clarified that we targeted the office with formal responsibility for each university's commercialization activities. We use the ubiquitous title of Technology Transfer Office (TTO) when referring to these offices.

\subsection{Data Collection}

Data collection involving 63 interviews with TTO executives in 22 universities across three continents (Europe, North America and Oceania) provided rich qualitative data and multiple instances of the phenomenon being explored. The selection of countries was primarily determined by the geographic location of the researchers. This was necessary as our intention to undertake an in-depth exploratory study needed locations in which researchers had knowledge of the university commercialization environment, the operation/structure of the TTO and were likely to gain appropriate access for face to face discussions. Also, because the focus of our research was on legitimacy-building, we purposefully selected countries and regions that provided diversity in both the level of experience of TTOs and the institutionalisation of academic entrepreneurship more generally. Our sample consisted of all eight university TTOs in New Zealand, all seven university TTOs in Ireland and a sample of seven university TTOs from the State of New York State in the United States (US). Seven universities from New York was regarded as sufficient as there was significant replication and patterns in the data collected across the sixth and seventh office contacted, suggesting a 
point of saturation had been reached in terms of participating TTOs. Of the seven universities selected in the US, six were private universities. Private universities are common in the US and are more commercially oriented in how they operate. Their inclusion in our study was, therefore, important to increase the variation of data collected to explore TTO identity shaping. Following assurances given to respondents, full details of participating TTOs are withheld for reasons of confidentiality. In any event, while we did have a preference for a cross-border study to see if the identity shaping strategies of TTOs were relevant across diverse countries and university ownership structures (i.e., public/private), our exploratory approach meant we deliberately chose not to control for contextual factors in our sites of study that might bias our interpretation of the data. Table 1 presents some high-level comparative demographic data on participating institutions (ownership and number of academic staff) and TTOs (year founded, staff numbers and interview respondents).

\section{INSERT TABLE 1}

We targeted the TTO Managing Director for interview and in each instance asked that he/she nominate additional personnel (e.g., commercialization officer, business development manager) for interview. Further interviews were sought until data collection reached a point of saturation (within each TTO) and the inputs of respondents began to overlap. In total, we conducted semi-structured interviews with 63 TTO management personnel (approximately 90 minutes each), thus averaging almost three interviews per office. As an introduction to each interview, we presented respondents with a definition of legitimacy for discussion. The interview guide focused on three key areas pertaining to TTO identity and legitimacybuilding - (1) how they presently viewed their office's legitimacy within the university; how they interacted with academics in their role; (3) how they interacted with university management in their role. 
Data collection also included secondary data sources such as annual reports, research brochures, research reports, case studies and press releases pertaining to participating institutions and TTOs. As well as confirming the positioning of commercialization as an active strategic initiative in the participating university, this material enhanced the validity of our methodology through the triangulation of different data sources (O'Donoghue and Punch, 2003, p. 78). We notified TTOs of our intention to gather and analyze secondary data prior to interviews to signal to interviewees that it was their office and not their own personal legitimacy and identity that was the subject of study. Confidentiality, and particularly the anonymity of respondents, represents a key component of this research and is reflected in the use of pseudonyms throughout. Assurances around this confidentiality were fundamental in both securing research access and in ensuring that respondents spoke freely about legitimacy challenges and their most immediate stakeholders. Our interviews amounted to over 700 pages of transcripts that were transcribed and sent back to interviewees for confirmation, and in most instances, editing.

\subsection{Data analysis}

Though our analysis overlapped with data collection, with preliminary patterns recorded in the form of shorthand notes (Miles and Huberman, 1994), data were primarily analyzed through a multi-coding process using NVivo software. This analysis was informed by Strauss and Corbin's (1998) grounded theory. In the first round of open coding two of the authors and a research assistant read each transcript and arranged the data into two high-level organizing categories titled "academics" (i.e., reference to professor, associate professor, lecturer, etc.) and "management" (i.e., references to Council, VP, VC, DVC, etc.).

A second round of deductive coding on TTOs' "identity shaping strategies" was then undertaken with codes derived from the identity-conformance (e.g., "compliance", "dominant 
norms", "reactive adjustment of internal practices", "tailoring behaviors" etc.) and identitymanipulation (e.g., "proactive sensing", "proactive interventions", “controlling perceptions", "persuasion"; "symbolic management", "lobbying", "publicizing added value" etc.) constructs developed earlier in the paper. A number of team meetings were held to compare and reach agreement on the deductive code titles and content. These meetings were essential to refine overlapping codes and to group similar ones into themes (or tree nodes). Once agreement was reached on these organizing themes, data within the two organizing categories ("academics" and "management") were independently coded. Following this process the "academic" data were reorganized within a subcategory titled "identity-conformance" and the "management" data were reorganized within a subcategory titled "identity-manipulation" Meetings among the research team were again held to ensure there was agreement on the coding outcomes. A total of eleven and nine themes contributed to the formation of these two subcategories respectively.

A third round of coding on "identity type" was next undertaken on the data organized within the two aforementioned subcategories. The three research team members utilized both deductive and inductive coding for this stage of the analysis. Specifically, deductive codes were derived from the paper's discussion on the multi-stakeholder university, while new themes and patterns relevant to "identity type" that inductively emerged outside of these codes were also noted. Following independent coding of the two subcategories, a number of meetings were held to reach agreement on how these data were interpreted. Our analysis indicated that identity-conformance was most suitably characterized by a "scientific identity" and that identity-manipulation was most noticeably characterized by a "business identity". A total of eighteen and fifteen themes contributed to the uncovering of these two identities respectively. 
A fourth and final round of analysis involved two linked stages. First, data within the original organization categories, "academics" and "management", were recoded, this time for evidence of TTO legitimacy. Second, akin to selective coding (Strauss and Corbin, 1998), team members met to compare this "legitimacy" data with the "identity-type" data (i.e., $3^{\text {rd }}$ order coding outcomes). Specifically, and in line with the primary purpose our research, team members discussed what patterns and inconsistencies existed between TTO attention towards "legitimacy" and TTO "identity types". This stage of analysis uncovered a number of potential identity-shaping problems within the data. Table 2 summarizes the overall coding process undertaken. In full, though primarily exploratory in nature, our findings stem from an iterative dialogue between the empirical data and theory (Eisenhardt and Graebner, 2007) that facilitates analytical generalizations (Yin, 2009) on how TTOs shape identity to build legitimacy with academics and management.

INSERT TABLE 2

\section{Results}

The primary focus of our research was to explore how TTOs build legitimacy by shaping identity within the university. In this section, we present our findings on this research. We find that TTOs use identity-conformance and shape a scientific identity to build legitimacy with university academics. As detailed earlier, identity-conformance involves TTOs deliberately adjusting and aligning their identity to promote sameness with the behaviors and norms they perceive as dominant among academics. We find that TTOs use aspects of identity-manipulation and shape a business identity to build legitimacy with university management. Legitimacy-building through identity-manipulation involves TTOs proactively sensing what is required and then shaping an identity that captures both their ability to meet these expectations as well as the unique or distinctive value of their role. Finally, we illustrate 
how this combination of identity strategies is proving ineffective for TTO legitimacybuilding within the university. We present these findings under the following three organizing categories: TTO legitimacy-building with university academics; TTO legitimacybuilding with university management; TTO legitimacy-building through identity: potential problems.

\subsection{TTO legitimacy-building with university academics}

In shaping a scientific identity, we find that TTOs are highly conformative in their legitimacy-building approach with academics. Utilizing identity-conformance as the primary legitimacy-building strategy reflects the centrality of the academic's role in the university environment and the fact that they are the most critical component in the TTO's value chain. For example, an Irish interviewee pointed out that "here, the academics rule the roost" (IREVI), while a US TTO executive commented “If we weren't aligned with their (academics') vision we would be told pretty quickly. XXX is all about its faculty and we are there to harvest the pearls of wisdom that they generate. So we are aligned with their research strategy because we follow behind it, we don't set it" (US-VIII Private). Thus, the TTOs in our study unanimously referred to the levels of power and autonomy held by academics and how their own strategy and functioning purposefully lagged behind that of academics.

Through identity-conformance TTOs acknowledge that they have little or no power or control over the quality, pace and quantity of scientific raw material provided by their suppliers, yet they are completely reliant on them and cannot afford to be disconnected. Despite often being aware of industry needs and market gaps, the TTO's position in the value chain is such that they are continuously challenged to adapt and up-skill across a wide variety of discipline areas within restrictive time constraints. There is, as Göktepe-Hultén (2008) pointed out, an expectation that TTOs will master the ability to be agile across a range of 
demands and leverage the entrepreneurial behaviors of beginners and occasional inventors, as well as experienced inventors, to justify their roles and involvement in the technology transfer process. This reliance on the academic community is apparent in the following comments from our data:

"As a business, TTOs are hopeless because you have no control over your supply, therefore you have no control over the markets you go for. You are always reacting. You need to develop some capabilities around every new idea or disclosure so you can understand it more and add value. Only then can you start conversations with industry" (NZ-III)

"You're limited, you can understand where the hotspots are, but being able to go after them is a function of your core competency set. If you don't have the necessary competencies, or if you have others in an area that is not hot then you're stuck, because universities cannot re-invent themselves in a technical field real fast" (US-VIII Private)

As illustrated in the following section, we found that TTO legitimacy-building with academics through identity-conformance specifically involved the shaping of a scientific identity.

\section{Identity-conformance: shaping a scientific identity with academics}

Many TTO executives referred to the importance of academic perceptions and how this had the potential to impede their legitimacy efforts. One New Zealand officer, for example, commented "(we need to) get more researchers into their comfort zone in terms of how they perceive us" (NZ-III). Likewise, another US TTO executive explained "The number of total contributing faculty is an important one (metric) for us because it shows the breadth people working with our office and trusting us. If we were to see the number go down sharply, it might be a sign that we're not doing enough outreach or that we have a perception problem" (US-VIII Private).

Our data indicate that, in response to these perception challenges, TTO executives deliberately shape a scientific identity to facilitate meaningful engagement with the academic community. As stated by one Irish TTO executive "You have to be able to have credibility and sensitivity towards the academic mind-set" (IRE-IV). Underpinning this strategy is a 
belief among TTOs that they risk being marginalized if they fail to effectively communicate and align the relevance of their role to traditional science. In line with this assessment, we found that TTOs are very careful in rationalizing how their commercialization focus and activities fit with the core purpose of university, namely the creation and dissemination of knowledge. Moreover it was evident that TTOs prioritized engagement with the academic community over industry:

"We put a lot of energy into communicating the value of our role to the university and securing buy-in at all levels. Once you have got that in play and the engine working so to speak you can be more market focused. By doing that you are then bringing the value back to the university and creating the good feeling and so it keeps going. But I suppose we have to really focus on building some key relationships with the university first" (NZII)

TTOs very deliberately publicize the recruitment of personnel with doctorates and other such scientific credentials in shaping this identity. These qualifications help promote equality and credibility with the scientific community. According to TTOs, this identity encourages the academic community to interact with TTO personnel as they feel their research will be understood and respected by the TTO. This point is reflected in the following comments of one TTO executive:

"The key capabilities are to be able to build those relationships with faculty members and staff and students and to make sure that they see you as an ally and not as an obstacle...you should not be seen as 'a suit' or part of the administration and management, you're one of them and this is where myself and some of my staff members coming from the faculty background are viewed as peers and not as management" (US- XI)

Table 3 presents some illustrative quotations on how TTOs shape a scientific identity in building legitimacy with university academics.

INSERT TABLE 3

As part of this identity-conformance strategy, we also found that TTOs make very deliberate efforts to develop relationships and trust with academics and to explain what services and value the TTO can offer. Specifically, consistent with the shaping of a scientific identity, TTOs initiate communication and dialogue in an unthreatening contract or technology-free environment in order to broaden their reach and enhance the potential for future engagement. 
Notably, this approach, which is often informal in nature, simultaneously allows the TTO to generate visibility, educate and update the academic community about the process, and to learn about the research environment so that they can factor potential research projects into their own planning. A number of comments illustrate this point:

"Technology transfer is a contact sport, the more time you spend on the ground talking to researchers the more invention disclosures you get. They learn more about the process, there is a two-way flow of information, you learn about them, they learn about you and the market. It's a relationship, it's all about trust" (IRE-IV).

"We knock on the doors of faculty and say 'this is our center, here is what we do, if you have something that comes out of something that you're working on, enlist our services'. So we build a relationship before the technology is ever invented and in that way we have trust and the bond. We have in my opinion a better idea of the pulse of the university" (US-VI Private)

"We would like to make the process more tangible...offering a means for early relationship building even in the absence of a cogent project and to make people familiar with us so the concepts are less foreign and we are not strangers (NZ-VI)

\subsection{TTO legitimacy-building with university management}

Legitimacy with university management is of fundamental importance to TTOs. A lack of legitimacy with university management can result in TTOs being under-resourced in their role, which in turn can deter their efforts to perform more effectively and to enhance their legitimacy. This point is reflected in the following comment:

"We would love to be more highly valued and more resourced and have more capability here to do these things, but like anything in a resource constrained environment you have to justify yourself before you can get to the next stage so it is a slow build - we have to manage our build incrementally and justifiably" (NZ-XII)

Our findings indicate that TTOs use identity-manipulation and produce a business identity to build legitimacy with university management. This identity is consistent with what TTOs perceive university management expect from them, as well as their own priorities around the commercialization of university science. In the subsection that follows, we describe how TTOs espouse behaviors and the deliberate use of processes that support this business identity in order to evoke positive evaluations from university management. 


\section{Identity manipulation: shaping a business identity with management}

In their interactions with university management, TTOs shape a business identity that emphasizes how their presence and the commercialization activities they advocate complement the strategic mandate of the university. In effect, they use a business identity to develop a business case for their existence. The shaping of this business identity was reflected in two key ways. First, in explaining how they use a deliberate and rigorous strategic planning process, TTOs depict a proficiency in business processes and use related terminology to achieve buy-in from university management:

"We pulled this business apart into its individual components, worked out where the barriers to our business were and what were the highest priority issues we needed to fix in order to get where we want to be in five years' time. This adds credibility to your thinking and helps the shareholder to embrace the strategy as they see that we have gone through a robust process" (NZ-II)

"We presented our strategy, not only to the team in here for feedback, but also back to the university. The VC and the Dean are on our board but we also reported back to the finance committee, to council, and the senior leadership team. The aim was really to get buy in as opposed to a hard sell - telling them "here is the process we have gone through, this is what we are trying to achieve, and here is how we are planning to do it." A lot of this was around our core purpose" (NZ-XIII)

Further evidence of how TTOs validate their business identity was apparent in their use of strategic goals and priorities to explain their overarching purpose, daily activities and measures of performance to university management:

"Money should never be a goal, money should be a result. Your goal is to disseminate that subset of new knowledge and if you do it right and for the right reasons and you do it well, money will come" (US-IV Public)

"We have a mission and vision, then we break that down and we have one, three and five year targets with specific KPIs. So we follow a very deliberate process in our activities, the idea being that, no matter the project, we understand how that contributes to the office's bigger picture. We actually have charts up all around the office showing where we are at, what the targets are and what the stretched targets are and where we are with those" (IRE-III)

"(Management know) it is very corporate here, we have our vision, our mission and our strategy clearly identified as well as our purpose and our values and they are something that drives us forward as we leverage them to develop our business" (NZ-I)

Second, TTOs explained how their commercialization and business expertise could benefit the university's performance. At a fundamental level, TTOs argue that their presence promotes entrepreneurial activities, the outcomes from which (e.g., patents, licenses, contract research etc.) can diversify university revenue streams for research funding - "Our services 
help diversify the revenue streams to the institution - there have been a couple of very important patent products that have generated significant revenues over the years" (US-VII

Private). TTOs also explained how they can contribute to the university's capacity to;

stimulate regional competiveness, foster closer connectivity with industry (e.g., joint research and start-ups), and positively impact local communities and society (e.g., health benefits). A number of views illustrate these findings:

"If it (IP) all goes to Washington DC they don't know what NY State need. Bayh-Dole enables us now to have more regional focus which is really necessitated because global competition is getting more severe. If we don't leverage what we have to try to help out the community that pay tax to support our research what good are we? (US-XII Private)

"It is not a case that financial incentives are the primary driver of commercialization as the reality is it is not going to make or break the university. We came to the view that it is about demonstrating to the community that we create new knowledge and it would be valuable to get business to uptake and use this knowledge and to create an economic benefit from it. We can then say we had a hand in that and that is why the tax payer funds us" (NZ-XII)

"There's been more emphasis in government on regional economic development in both New York City and New York State and entrepreneurship can be supportive of that - if we can create companies locally versus licensing the companies elsewhere it promotes economic development and helps promote the visibility of the university (US-X Private)

Added to these benefits, we found evidence pertaining to the TTOs' argued ability to enhance the reputation of their respective universities. This can involve helping to keep universities relevant to industry and prospective students and staff globally. More specifically, TTOs emphasize how commercialization activities and an (business oriented) innovative environment can attract and retain productive staff and students, particularly given the likelihood that entrepreneurship and innovation will be increasingly important for universities in the future. The following comments illustrate these findings, while Table 4 presents some additional supporting quotations on how TTOs shape a business identity in building legitimacy with university management.

"Through a commercialization lens we are trying to help build the reputation of the university, its standing across the globe and how it compares to its peers. In that context commercialization has a very strategic role in the functioning of the university" (NZ-XII)

"Our president's speeches often mention the latest commercialization success. It is an opportunity for us to boast and improve the perception of being a professional research services institute" (IRE-XVI) 
"Maintaining good faculty is an important strategic goal of the university. What our office does helps retain and attract research intensive and creative faculty" (US-I Private)

"Innovation and successful technology transfer could be a very valuable reputational and retention recruitment tool. Younger researchers are going to have different expectations of what their career means from what it is now. You could offer them this fascinating career where you can teach, research and do innovation - what a great and exciting job" (NZ-VI)

INSERT TABLE 4

\subsection{TTO legitimacy-building through identity: potential problems}

We have presented evidence of how TTOs use both identity-conformance and identitymanipulation to build legitimacy with university academics and management respectively. However, in the subsections that follow we illustrate how this combination of identityshaping strategies appears to be ineffective.

\section{Ineffectiveness of identity-conformance with university academics}

Despite TTOs' efforts to build legitimacy by purposefully conforming to the scientific identity of the academic community, TTOs report that academics continue to directly intervene in what they believe is their core role. This intervention includes interrupting the negotiation process between the TTO and investors/clients to influence the direction of the technology, and deliberately avoiding the input of the TTO, thus detrimentally effecting efforts to develop experience and critical mass within the TTO. This point is illustrated in the following comments:

"An important conflict is when a commercial entity is at the doorstep and wanting to get a license and makes demands that are not advantageous to the institution and the faculty person says 'just do it' because he's afraid that the potential licensee will walk away - that's where a lot of value goes out the door (US-VII Private)

"I was threatened three times by academics for the way I interpreted the university IP policy. A lot of those senior academics were throwing their weight around" (IRE-XXIV)

"There are a few academics who always think they know best. This sends a message out to all the rest of the academics that they know best and they don't. Also they often scupper the chances of selling that bit of IP as they have done it in a half botched kind of way rather than picking the right partner so it can be quite frustrating" (NZ XVII) 
Furthermore, TTO executives report how, despite their legitimacy-building efforts, academics undermine the TTO by taking them for granted and simply treating them as a means to an end for the purpose of acquiring funds or form filling. Again, a number of comments illustrate this finding:

"It has been more of a mercenary process with the academic saying 'this is what I think government or industry wants to hear. They have a box about commercial activity so I will go and talk to XXX and see if they can give me words to put in' - then that is the last you will hear from them which is not very good." (NZ-I)

"When things go right, they (academics) forget about your contribution, when things go wrong, they say you held them up. The business partners will say you are over-valuing the technology" (IRE-VII)

"In many quarters in the university there is a sense of "just give us the money you only have to pass it through to us, we might have to jump through some loops but we are willing to jump through them"” (NZ XV)

Interestingly, our findings indicate that in using identity-conformance to align with what they perceive as the dominant norms and expectations in the university, TTOs may be underestimating some of the core needs of the academic community. For example, TTOs referred to the importance of hiring in specific business, legal and marketing expertise in the form of consultants, as well as being associated with relevant industry bodies and commercialization networks to ensure best practice is being adopted. According to TTO executives, these consultancy services and agency connections enhance their legitimacy within the academic community, as well as their ability to perform more effectively. Together, these findings provide evidence that TTOs may be overlooking the importance the academic community place on business and commercial expertise when shaping their identity. A number of quotations illustrate this point:

"We sometimes use external experts to bring things to market and to build those connections rather than us always trying to learn new things...(so) we sometimes bring in consultants (with) expertise in a particular area. We get a lot of credibility with the academic community for that (NZ-III)

"We get a small budget to buy external experts and that augments our own skill set. They also give us access to the national organizations that we need to belong to in order to help us do a better job" (US-III Private)

"A key part of the model and one of the skills we need is the ability to find external consultants or agencies that provide commercialization services or expertise that we could utilize in our projects - we don't tend to do it all ourselves" (NZ-IX) 
Thus, we find that shaping of a scientific identity through identity-conformance is proving ineffective for TTO legitimacy-building. This is evident through interventions, avoidance and a lack of buy-in by the academic community. We also find evidence indicating that a scientific identity may be misaligned with the primary determinants of legitimacy among the academic community. Commercial and business development skills are presumably valued by the academic community because they represent competencies and perspectives that they may not have access to. Despite TTOs acknowledging the value placed on these skills by academics, we find that they shape a scientific identity with this academic community.

\section{Ineffectiveness of identity-manipulation with university management}

The use of identity-manipulation by TTOs to build legitimacy with university management appears to be equally ineffective. TTOs expressed the view that, despite their efforts to shape a business identity, their position in the university remains unclear - "we have had two consultants come in 2006 and last year and they both made the same conclusion that the upper administration really has not articulated a clear role for technology transfer at our university" (US-V Public). Specifically, TTOs report that there is a lack of belief and meaningful engagement and enthusiasm from management on their position in the university.

"To some extent the upper administration looks upon us as a necessary evil and an expense that we have to fulfil if we are going to accept Federal money because of the Bayh Dol Act. That may be overstating the case but I think (they) don't ever think this is going to come to much or else it's going to take so long that nobody will be around to enjoy it (US-V Public)

"There seems to be a lack of championing really. I think that the people who are on the innovation bandwagon in the university might have other agendas beside pure development of technology" (IRE-XXVIII)

"Quite honestly there's more lip service given to the function and its importance than actually listening to the function itself to find out what it needs and providing the right staff" (US-III Private)

Many TTOs also expressed frustrations with inconsistencies in support at different levels of leadership in the university, particularly at the level of School/Deans and Department/HOD. Furthermore, we found that TTOs feel their legitimacy-building efforts are being inhibited by 
inadequate and cautious integration into the university's formal strategic intentions (i.e., as articulated in annual reports and strategic plans). These points are illustrated in the following comments:

"I feel like we are the tail and we cannot wag the dog. They quietly slipped in to their strategic plan some terms like 'we need to be more enterprising' so even the language they are using is cautious...what I would love to see is for them to say "the commercialization opportunity is the third leg of the stool. The world needs this"' (NZ$\mathrm{VI})$

"Not all heads of department are supportive. Some continue to put greater emphasis on meeting teaching commitments and so on, so garnering support and allowing people the space to contribute to this movement would be very helpful" (NZ-IX)

"The people who run the institution should be talking about (our role) and essentially demanding that faculty is supportive of the goals of the institution. That is often done in rhetoric but not in practice which is quite unfortunate" (US-XII Private)

Finally, it should be noted that the ineffectiveness of identity-manipulation is not only problematic for TTO legitimacy with university management. We found that TTO

legitimacy-building activities and standings with university management and academics are not detached from each other, but instead are very much interrelated. Illustrating this point we found a clear expectation among TTO executives that university management could do more to support them in their role, which could in turn help the TTO overcome legitimacy challenges experienced in their interactions with the academic community:

"In this institution the spirit is willing but the body is weak. You have to have a long-term perspective. (Management) need to support (us) in the face of faculty not understanding what they are doing or looking to accept a horrible deal for short-term money" (US-X Private)

"If the senior academic leadership is not telling people to do $\mathrm{x}, \mathrm{y}$ or $\mathrm{z}$ it can be an uphill battle. So when people decide 'well I'm going to make my own deal and don't get in my way' and the leadership doesn't say 'wait a minute this is institutional property it's not yours', then those people will not be cooperative. (US-VII Private)

"A major hindrance is simply the lack of insistence by the academic leadership that faculty have got to go beyond being cooperative with the folks who are trying to commercialize inventions, that is the biggest problem" (US-VXI Private)

"Sending out a proper message is very important to make sure faculty understand the university expectation is not just to do good research and get a publication, it is to do good research and make sure results are beneficial for society" (US-II Private) 
In sum therefore, after exploring how TTOs build legitimacy by shaping identity within the university, our core findings are twofold. First, to build legitimacy, TTOs shape a dual identity, one scientific and the other business, with university academics and management respectively. Specifically, TTOs prioritize the key determinants of legitimacy with academics as scientific credibility and management as alignment with the university strategy and use identity-conformance and identity-manipulation accordingly.

Second, we find that this combination of identity-conformance and identitymanipulation is proving ineffective for legitimizing the TTO within the university. Furthermore, legitimacy discounts are compounded by TTOs underestimating the actual determinants of legitimacy among the academic community (i.e., business expertise), as well as university management providing insufficient traction for TTOs to realize their strategic potential on behalf of the university. Table 5 presents a summary of these research findings. Next, we elaborate on the implications of these research findings.

INSERT TABLE 5

\section{Discussion}

This research has implications for scholars, TTO executives and university management. In the sections that follow we explain these theoretical and practical implications in more detail.

\subsection{Theoretical implications}

The findings from our research contribute to our theoretical understanding of how identity interacts with legitimacy, particularly in the areas of multiple identities, social cues and identity distinctiveness. We present these contributions as propositions. 


\section{Multiple identities and legitimacy}

When two principals exist in an agency relationship, multiple expectations naturally arise. For TTOs, these expectations can sometimes conflict due to the continuing overlap between science and business in the university. Our findings would suggest that TTOs attempt to manage this conflict by shaping a dual identity, one scientific and the other business, with university academics and management respectively. Our findings clearly indicate, however, that this combination of dual identities is proving ineffective for the purpose of building legitimacy with two principals. These results have some support, with existing literature already highlighting the complexity of having to combine and sequentially switch between multiple identities (Kistruck et al., 2013; Kreiner et al., 2009; Zhang et al., 2006). Furthermore, when interacting with two principals, prioritizing one can undermine the other (Dunn and Jones, 2010; Jarzabkowski and Fenton, 2006; Kraatz and Block, 2008). Therefore, adding to these perspectives, we propose that, when building legitimacy with two principals (e.g., academics and management), shaping and blending two contradictory identities (e.g., scientific and business) blurs identity and ultimately diminishes legitimacy with both principals. We summarize this in the following proposition:

P1: When building legitimacy with two principals, shaping contradictory identities diminishes legitimacy.

\section{Social cues and legitimacy}

Our findings also have implications for the role of social cues (Ashforth and Johnson, 2001; Gioia et al., 2000) in identity-shaping and legitimacy-building. We illustrate how TTOs' identity conformance strategy with academics was misaligned. Specifically, in detecting what identity to conform to when interacting with university academics, TTOs underestimate some of the core requirements and expectations of this target audience. Despite TTOs 
acknowledging that business and commercial expertise were important determinants of legitimacy among the academic community, TTOs concentrated on shaping a scientific identity. Our findings, therefore, emphasize how misinterpreting social cues can lead to misaligned identity shaping strategies that ultimately damage legitimacy. Again we summarize these findings in the following proposition:

P2: When shaping identity, misunderstanding social cues can result in legitimacy discounts.

\section{Identity distinctiveness and legitimacy}

Our findings indicate that both identity shaping strategies, identity-conformance and identitymanipulation, borrow from the principals' identities. The strategies are, therefore, relatively similar in the sense that they depend, albeit to different degrees, upon the existing identities of academics and management. Through identity-conformance, TTOs clearly promote homogeneousness with the dominant norms and expectations of academia (i.e., scientific identity). Through identity manipulation, TTOs proactively sense what they believe is required or anticipated from university management and then shape an identity that captures their ability to meet these expectations (i.e., business identity). What becomes apparent from our findings, therefore, is that TTOs' use of identity-manipulation appears to be incomplete. More specifically, in our theoretical framing, we explained that TTOs' use of identitymanipulation would involve shaping an identity that not only aligned with anticipated requirements, but also was in some way distinctive and which captured the unique value of their role.

With this in mind, we suggest an alternative explanation for the ineffectiveness of TTOs' legitimacy-building efforts. Rather than characterizing their identity-shaping strategies as incorrect, we propose that they are merely unfinished. In particular, our findings indicate that TTOs are inadequately managing the challenging dilemma of sameness and uniqueness 
in their identity (Navis and Glynn, 2010). Instead of achieving an identity that is "optimally distinctive" (Brewer, 1991), their identity appears to be prioritizing "fitting in" and satisfying the requirements of both principals but stopping short of simultaneously differentiating themselves from the university environment. TTOs appear to be focused on avoiding conflict by positioning their identity as relevant to both principals rather than offering an alternative (Fagerberg et al., 2012). This is problematic as theory informs us that legitimacy is as dependent on being different as it is on being the same (Deephouse, 1999). Interestingly, however, TTOs appear to be adopting a familiar route in the legitimation process. Before an organization, particularly those operating in highly institutionalized environments such as universities, can develop legitimacy through claims of individuality and differentiation, it must contribute to and secure its membership within a much broader, shared and collective identity or category. Adhering to this collective category represents the minimal standard for membership but thereafter organizations can and should exercise differing degrees of autonomy to stand out and distinguish their identity (Glynn and Navis, 2013). Theoretical support for this staged process of legitimization is provided by a number of scholars including: Chaney and Marshall's (2013) examination of how music festival organizers concentrate on being recognized as socially legitimate actors (e.g., with regulators and sponsorship institutions) before considering how to compete and earn profits; Navis and Glynn's (2010) study of the emergence of satellite radio and how it first became normalized as a new product category; and Rosa et al.'s (1999) research on how market acceptance of the minivan as a legitimately new vehicle form preceded competitors' efforts to differentiate each other within the minivan market segment. Likewise, Navis and Glynn (2011) argued that in established market contexts, identity claims must prioritize legitimacy through close alignment with the market category before deviating towards a posture they refer to as "legitimately distinctive". Also, in their study of registered nurses, Goodrick and Reay (2010) 
found that when legitimizing a new professional identity, it is essential that the past and broader institutional environment is not delegitimized but rather neutralized and leveraged for the purpose of legitimizing the emerging role identity.

Therefore, we propose that in order to become (more) legitimate, TTOs should consider progressing their identity-shaping efforts beyond conformance and (partial) manipulation. In effect, we see their current identity shaping strategies as representing their efforts to build legitimacy within the broader university category. Becoming a part of this collective and shared university identity can strengthen the TTO's similarity and appeal to evaluating principals (academics and management) within the category. Indeed, as already illustrated in our findings, TTOs are clearly prioritizing how to fit in with academics and management within the university. The following quotes serves as a reminder of this focus among TTOs:

"I have never heard of one faculty inventor worry about regional economic development or the overall reputation of the university. Most of them when they have an invention try to see how they can make the most money for themselves. If the university tells me to sell it to the highest bidder I can almost assure you that most of our inventions will end up in foreigner's hands and will not benefit the US and will certainly not create jobs here. So our institutional agenda is much broader that the individual agenda" (US-II Private)

In order to develop its legitimacy standing and become recognized as a value-adding and unique actor in the university, TTOs may need to begin individuating their identity from the expectations of these same principals and the established norms within the university. Given the entrepreneurial and innovative activities that TTOs champion (e.g., start-ups, patents, licensing), claims of distinctiveness to complement their identity conformance seem particularly important in order to gain legitimacy. As argued by Navis and Glynn (2011, p.479), "conformity to established standards is antithetical to entrepreneurship, which tends to be more concerned with novelty, distinctiveness and nonconformity”. Our final propositions, therefore, advocate that TTOs fully extend their use of identity-manipulation to incorporate identity distinctiveness. In shaping their own distinctive identity in this manner, TTOs could build on and complement their existing use of identity-conformance and identity- 
manipulation when shaping scientific and business identities respectively. More specifically, TTOs could build legitimacy through a combination of conforming to dominant academic norms (identity-conformance), sensing and meeting anticipated requirements from management (identity-manipulation), together with shaping a unique value-adding identity as guided by their own distinctive values, beliefs and models (identity-manipulation). Interestingly, creating and leveraging distinctiveness is not only important for establishing legitimacy. Murray (2010) argued that the conflicting stakeholder expectations that TTOs experience from the overlapping boundaries of science and business can also be managed by reinforcing distinctiveness. This leads us to develop the following proposition:

P3: When building legitimacy with two principals in a highly institutionalized environment, an organization must incorporate identity-manipulation, where identity-manipulation involves shaping an identity that both meets the anticipated requirements of evaluating audiences and is sufficiently distinct from the norms and expectations of these same evaluating audiences.

Just as our findings illustrated the legitimacy limitations of depending on identityconformance, excessive or sole use of identity-manipulation to shape a distinctive identity is unlikely to build legitimacy. There would be little point in TTOs becoming so distinctive that they eroded their efforts towards gaining acceptance and a shared identity within the university. Ferlie et al. (2005), for example, argued that excessively strong professional identity boundaries or states of distinctiveness can slow innovation spread, an outcome that is highly likely to damage TTO productivity. We suspect that both identity-conformance and identity-manipulation strategies are heavily intertwined with processes of legitimation, and that ultimately TTO legitimacy is dependent on an appropriately balanced combination of both strategies in their entirety. Furthermore, in terms of timing, we suspect that the creation 
of a distinctive identity will only be effective after the TTO has secured institutional acceptance or social legitimacy in the university through identity-conformance and (preliminary) identity-manipulation. Without first shaping identity through conformance, efforts to deviate from dominant norms and expectations may result in legitimacy discounts (Elsbach and Kramer, 2003; Hsu and Hannan, 2005). This leads us to develop three final propositions, with each serving to re-emphasize the important interdependence between collective and distinctive identities that appears so prominently in the legitimacy literature. Figure 2 summarizes our contribution on the relationship between TTO identity shaping strategies and TTO legitimacy.

P4: When building legitimacy with two principals in a highly institutionalized environment, an organization must appropriately balance both identity-conformance and identitymanipulation.

P5: When building legitimacy with two principals in a highly institutionalized environment, identity-conformance precedes identity-manipulation.

P6: When building legitimacy through identity-manipulation with two principals in a highly institutionalized environment, meeting the anticipated requirements of evaluating audiences precedes shaping a distinct identity.

INSERT FIGURE 2

Therefore we suggest that in order to have a legitimate presence within the university, scholars and management must recognise the identity of the TTO as being distinct from their own. Identity-conformance and identity-manipulation are the process by which this distinctive identity is shaped and recognised. These propositions arise from a combination of our findings regarding the inadequacy of identity-conformance and (partial) identitymanipulation strategies to build legitimacy coupled with a theoretical prediction for how 
legitimacy is created. While we do not have a strong empirical foundation from this study to illustrate how exactly TTOs can shape their distinctive identity, our data does indicate that TTOs are becoming aware of the importance of having a value-adding and clearly differentiated identity. This is captured in following quotations:

\footnotetext{
"Researchers are not silly people and they will make a motivational judgment call...and say well how can you help us when they meet us - what are your resources, knowledge and expertise? - Why should we work with you? Who are your connections? How can you move my project forward? - so if we don't have money for proof of concepts which are quite expensive for health sciences, then no offence but why would they deal with us?" $(\mathrm{NZ}-\mathrm{X})$
}

"We want to provide a channel for knowledge to industry so I want to position this office in such a way that industry will come here seeking opportunities and researchers will come to us because of our connections to industry and in turn they will see xxx as a way to get their knowledge to market" (IRE-XXII)

"There is a perception among many PIs that we operate as a gatekeeper...so it is very much to move from a gatekeeper who just applies the rules and enforces compliance to being here to assist, facilitate and help them get a better result (NZ-IX)

\subsection{Practical implications}

For TTO executives, these propositions offer a possible extension to their widely accepted identity as neutral intermediaries or brokering actors between universities and industry (Clarysse and Moray, 2004; Markman et al., 2005; Phan and Siegel, 2006; Powers and McDougall, 2005 Siegel et al., 2003). Specifically, our findings propose that TTOs consider progressing beyond balancing the expectations of their two core principals and concentrate on developing their own unique identity. Creating their own unique mission, objectives, structure, training, community of practice and even funding models (e.g., crowd funding) could provide TTOs with a distinctive identity that complements and reinforces preliminary legitimacy claims made through conformance and manipulation. Thus, we suggest that TTO legitimacy is dependent on their ability to more clearly communicate the value-adding potential of their commercial purpose, following and in addition to conforming to the dominant norms of academia and aligning with the strategic imperatives of their host institution. For example, rather than solely utilizing their scientific credentials, relationshipbuilding and innate respect for academic science as a means of blending science and 
business, TTO executives may be better served if they could also incorporate these academic skill-sets to create and reinforce their own distinctive identity.

Ultimately, TTOs need to shape an identity that will provoke engagement with their office due to its distinctiveness and variation from what is usually available in a university. TTO legitimacy cannot arise when being solely viewed as an administrative function or a cash generating instrument run by people with a confusing identity, partially academic and partially business. However, if TTOs are to shape an element of distinctiveness into their identity that is no way subordinated by university academics or management it is important that the components underpinning these claims of distinctiveness are also central and enduring TTO attributes (Whetten, 2006). For example, if TTOs failed to fully incorporate their competencies when shaping a distinctive identity they would risk projecting an identity that is misaligned with their ability to exercise behaviors consistent with this identity. Such "competency" misalignments could be harmful to their legitimacy-building efforts. In this sense, in order to build legitimacy, TTOs may need to consider explicitly attending to the questions of "Who are you?" "What is your purpose and vision?" and "Why are you the best option?", in addition to explaining how they fit in and how they can potentially help. Even if this individualistic identity is criticized, the attention will at a very minimum recognize and reinforce TTO distinctiveness.

We believe our findings are also particularly timely for TTO executives. For example, Boehm and Hogan's (2014) suggestion that it is now academic Principal Investigators, not TTOs, who have the dominant responsibility and influence in initiating, bridging and coordinating university-business relations, would indicate that TTOs need to (re)claim their identity as a matter of urgency. Moreover, our findings and associated proposals provide an extension to our current understanding of why the academic community frequently refers to skills gaps among TTOs (Chapple et al., 2005; Mustar et al., 2006; O’Shea et al., 2005; 
Swamidass and Vulasa, 2009) and/or choose to avoid adopting the services of TTOs

(Aldridge and Audretsch, 2011; Bodas-Freitas et al., 2013; Link et al., 2007; Shane, 2004;

Siegel et al., 2003, 2004; Thune and Gulbrandsen, 2011).

Finally, our results indicate that university management are a key dependency for TTOs' legitimacy with academics. Specifically, university management are in a position whereby they can support TTOs' efforts to create a distinguishable identity. They can articulate the university's position on commercialization and publicize the role, function and purpose of the TTO within the broader institution. Formalizing the TTO's own unique identity within the university's strategic documents and objectives and communicating it officially to all levels of university management (i.e., heads of divisions, schools and departments) as well as to university academics may help to provide clarity and consistency. A number of scholars report how entrepreneurial activity is heavily dependent on the types of influence and support at a more micro and departmental level in the university (Bercovitz and Feldman, 2008; Louis et al., 1989; Rasmussen et al., 2014). Previous literature also points to the importance of sufficiently transparent IP regulation, mission clarity, supportive remuneration and promotion policies within the university to promote an entrepreneurial culture and to complement the commercialization functions of the TTO (Baldini et al., 2006; Debackere and Veugelers 2005; Friedman and Silberman 2003; O’Shea et al., 2007). Our proposals extend these findings by highlighting the importance of this matter for TTO identity and legitimacy-building. Specifically, university management can complement TTOs' efforts to create a distinctive identity. If university management do not take such steps, cautious language and unclear expectations run the risk of (re)blurring the boundaries between science and business, thus detracting from TTO legitimacy-building efforts to build on the divide as a productive tension. 


\section{Concluding comments and future research}

The primary focus of our research was to explore how TTOs build legitimacy by shaping identity within the university. To address this research subject, we developed two identityshaping constructs, identity-conformance and identity-manipulation. We find that TTOs shape a dual identity, one scientific and the other business, with university academics and management respectively. TTOs prioritize the key determinants of legitimacy with academics as scientific credibility and management as alignment with the university strategy and use identity-conformance and identity-manipulation accordingly. However, we also find that this combination of identity-conformance and identity-manipulation appears to be proving ineffective for legitimizing the TTO within the university.

These findings have a number of implications for legitimacy and identity theory. First, we propose that, when building legitimacy with two principals, shaping and blending two contradictory identities distorts identity and ultimately diminishes legitimacy with both principals. Second, we emphasize how misinterpreting social cues, namely the expectations and requirements of evaluating audiences, can lead to misaligned identity shaping strategies that damage legitimacy. Third, we propose that, when building legitimacy in highly institutionalized environments, identity-conformance and identity-manipulation precede but ultimately depend on and are intertwined with identity-distinctiveness. We conclude that TTOs' identity shaping strategies should not necessarily be considered ineffective, but instead may be simply incomplete or under development. TTO executives are, therefore, encouraged to shift their attention towards shaping a distinctive identity that complements and reinforces preliminary legitimacy claims made through conformance and manipulation.

Our research is not without limitations. Although we deliberately undertook our research from the perspective of TTO executives, our findings could be enhanced by incorporating the views of university academics and management on this same subject. Specifically, it would 
be interesting to find out how academics and management perceive the identity of the TTO and to what extent these identity-shaping strategies are recognized and/or valued by both principals. Acknowledging the level of (mis)alignment between TTOs and these two principals is fundamental to understanding the overall legitimacy of the TTO. Furthermore, while our focus was on TTO identity and legitimacy within the university environment, future researchers should consider incorporating external stakeholders such as industry partners, specialist consultants, governmental bodies and professional agencies. TTO interactions with these stakeholders may have significant norming effects that influence TTO identity strategies and legitimacy-building. As stated by Rao et al. (2000, p. 270) "organizations acquire a social identity from the industry to which they belong, the organizational form they use, and through membership in accrediting bodies". The rich potential of this particular line of inquiry is apparent in our findings detailing how TTO recognize the legitimacy benefits arising from hiring in specialist consultants and their association with industry and commercialization networks.

The exploratory nature of our research was such that the identification of how TTOs shape identity to build legitimacy with two principals was our core focus. We recognize that a logical next step for these exploratory results and their associated propositions is to examine their validity. Therefore, we encourage future researchers to examine whether and to what extent the TTO identities (scientific and business) and identity-shaping strategies (identityconformance and identity-manipulation) we presented are evident in other universities. We are particularly interested in understanding how contextual factors and different institutional environments influence the prevalence and effectiveness of these identity strategies. For example, are these strategies relevant to other geographic locations internationally? How do the size, experience, performance and resource base of the TTO influence their identityshaping strategies? How do the size, age and discipline breadth/depth of the university 
influence TTO identity-shaping? Given how levels of academic entrepreneurship are influenced by entrepreneurial infrastructure (Di Gregorio and Shane 2003; Feldman and Francis, 2003); peer support (Etzkowitz, 2002; Stuart and Ding, 2006) and other university specific characteristics (O’Shea et al. 2005; Powers and McDougall, 2005; Mustar and Wright, 2010), we believe the inclusion of such contextual factors could significantly enhance our understanding of how TTOs shape identity. Finally, theorists and practitioners alike would benefit from research findings that support or contest our propositions on identity-distinctiveness. How exactly can TTOs shape a distinctive identity? As explained by Navis and Glynn (2011), having elements of conformance and distinctiveness is not enough for legitimacy, more important than this is the integration between both of these elements into a meaningful whole. Establishing how TTOs can build their legitimacy and achieve such coherence through identity shaping strategies promises to provide a rich line for inquiry for future researchers.

\section{References}

Albert, S., Adams, E., 2002. The hybrid identity of law firms, in Soenen,G., Moingeon, B. (Eds), Corporate and Organizational Identities: Integrating Strategy, Marketing, Communication and Organizational Perspectives. Routledge, New York, pp. 35-50.

Albert, S., Whetten, D.A. 1985. Organizational identity. Research in Organizational Behavior 17, 263-95.

Aldridge, T.T., Audretsch, D., 2011. The Bayh-Dole Act and scientist entrepreneurship. Research Policy 40, $1058-67$.

Ambos, T.C., Mäkelä, K., Birkinshaw, J., D’Este, P., 2008. When does university research get commercialized? Creating ambidexterity in research institutions. Journal of Management Studies 45, 1424-47.

Ashforth, B., Gibbs, B., 1990. The double-edge of organizational legitimation. Organization Science 1(2), 17794.

Ashforth, B., Harrison, S., Corley, K., 2008. Identification in organizations: an examination of four fundamental questions. Journal of Management 34, 325-74. 
Ashforth, B., Humphrey, R., 1993. Emotional labor in service roles: the influence of identity. Academy of Management Review, 18, 88-115.

Ashforth, B., Johnson, S., 2001. Which hat to wear? The relative salience of multiple identities in organizational contexts, in Hogg, M., Terry, D. (Eds), Social Identity Processes in Organizational Contexts. Psychology Press, Philadelphia, pp. 31-48.

Baldini, N., Grimaldi, R., Sobrero, M., 2006. Institutional changes and the commercialization of academic knowledge: a study of Italian universities' patenting activities between 1965 and 2002. Research Policy 35, 518-32.

Bercovitz, J., Feldman, M., 2008. Academic entrepreneurs: organizational change at the individual level. Organizational Science 19, 69-89.

Bitektine, A., 2011. Towards a theory of social judgments of organizations: the case of legitimacy, reputation, and status. Academy of Management Review, 36(1), 151-79.

Blumenthal, D., Campbell, E.G., Causino, N., Louis, K.S., 1996. Participation of life-science faculty in research relationships with industry. New England Journal of Medicine 335, 1734-39.

Bodas Freitas, I.M., Geuna, A., Rossi, F., 2013. The governance of university-industry knowledge transfer: why small firms do (not) develop institutional collaborations? Research Policy 42, 50-62.

Boehm, D., Hogan, T., 2014. 'A jack of all trades'-The role of PIs in the establishment and management of collaborative networks in scientific knowledge commercialization. The Journal of Technology Transfer 39, 134-49.

Bozeman, B., 2000. Technology transfer and public policy: a review of research and theory. Research Policy 29 , 627-55.

Brewer, M.B., 1991. The social self: on being the same and different at the same time. Personality and Social Psychology Bulletin 17, 475-82.

Brickson, S.L., 2005. Organizational identity orientation: making the link between organizational identity and organizations' relations with stakeholders. Administrative Science Quarterly 50, 576-609.

Brown, A., Toyoki, S., 2013. Identity work and legitimacy. Organization Studies 34, 875-96.

Burke, P., 1980. The self: measurement requirements from an integrationist perspective. Social Psychology Quarterly 43, 18-29.

Bush, V., 1945. Science: The Endless Frontier; A Report to the President by Vannevar Bush, Director of the Office of Scientific Research and Development. Government Printing Office, Washington, DC. 
Campbell, E.G., Weissman, J.S., Causino, N., Blumenthal, D., 2000. Data withholding in academic medicine: characteristics of faculty denied access to research results and biomaterials. Research Policy 29, 303-12.

Chaney, D., Marshall, R. 2013. Social legitimacy versus distinctiveness: mapping the place of consumers in the mental representations of managers in an institutionalized environment. Journal of Business Research 66, $1550-58$.

Chapple, W., Lockett, A., Siegel, D., Wright, M., 2005. Assessing the relative performance of UK university technology transfer offices: parametric and non-parametric evidence. Research Policy 34, 369-84.

Chermak, S., Weiss, A., 2005. Maintaining legitimacy using external communication strategies: an analysis of police-media relations. Journal of Criminal Justice 33, 501-12.

Clarysse, B., Moray, N., 2004. A process study of entrepreneurial team formation: the case of a research-based spin-off. Journal of Business Venturing 19, 55-79.

Clarysse, B., Tartari, V., Salter, A., 2011. The impact of entrepreneurial capacity, experience and organizational support on academic entrepreneurship. Research Policy 40, 1084-93.

Colombo, M.G., Delmastro, M., 2002. How effective are technology incubators? Evidence from Italy. Research Policy 31, 1103-22.

Colyvas, J.A., 2007. From divergent meanings to common practices: the early institutionalization of academic entrepreneurship in the life sciences. Research Policy 36, 456-76.

Colyvas, J.A., Jonsson, S., 2011. Ubiquity and legitimacy: disentangling diffusion and institutionalization. Sociological Theory 29, 27-53.

Colyvas, J.A., Powell, W.W., 2006. Roads to institutionalization: the remaking of boundaries between public and private science. Research in Organizational Behavior 27, 305-53.

Colyvas, J.A., Powell, W.W., 2007. From vulnerable to venerated: the institutionalization of academic entrepreneurship in the life sciences. Research in the Sociology of Organizations 25, 219-59.

Daraio, C., Bonaccorsi, A., Geuna, A., Lepori, B., Bach, L., Bogetoft, P., Cardoso, M., Castro-Martinez, E., Crespi, G., de Lucio, I.F., Fried, H., Garcia-Aracil, A., Inzelt, A., Jongbloed, B., Kempkes, G., Llerena, P., Matt, M., Olivares, M., Pohl, C., Raty, T., 2010. The European university landscape: a micro characterization based on evidence from the Aquameth project. Research Policy, 40, 148-64.

Dasgupta, P., David, P.A., 1994. Toward a new economics of science. Research Policy 23, 487-521.

D’Este, P., Perkmann, M., 2011. Why do academics engage with industry? The entrepreneurial university and individual motivations. Journal of Technology Transfer 36, 316-39. 
Debackere, K., Veugelers, R., 2005. The role of academic technology transfer organizations in improving industry science links. Research Policy 34, 321-42.

Decter, M., Bennett, D., Leseure, M., 2007. University to business technology transfer: UK and USA comparisons. Technovation 27, 145-55.

Deephouse, D.L., 1999. To be different, or to be the same? It's a question (and theory) of strategic balance. Strategic Management Journal 20(2), 147-66.

Denis, J.L., Langley, A., Rouleau, L., 2007. Strategizing in pluralistic contexts: rethinking theoretical frames. Human Relations 60, 179-215.

Di Gregorio, D., Shane, S. 2003. Why do some universities generate more start-ups than other? Research Policy 32(2), 209-27.

Dowling, J., Pfeffer, J., 1975. Organizational legitimacy: social values and organizational behavior. Pacific Sociological Review 18, 122-36.

Drori, I., Honig, B., Wright, M., 2009. Transnational entrepreneurship: an emergent field of study. Entrepreneurship Theory and Practice 33, 1001-22.

Dunn, M., Jones, C., 2010. Institutional logics and institutional pluralism: the contestation of care and science logics in medical education, 1967-2005. Administrative Science Quarterly 55, 114-49.

Dutton, J.E., Dukerich, J.M., 1991. Keeping an eye on the mirror: image and identity in organizational adaptation. Academy of Management Journal 34, 517-54.

Dutton, J.E., Dukerich, J.M., Harquail, C.V., 1994. Organizational images and member identification. Administrative Science Quarterly 39, 239-63.

Eisenberg, E.M., 1984. Ambiguity as strategy in organizational communication. Communication Monographs $51,227-42$.

Eisenhardt, K.M., 1989. Agency theory: an assessment and review. The Academy of Management Review 14, $57-74$.

Eisenhardt, K.M., Graebner, M.E., 2007. Theory building from cases: opportunities and challenges. Academy of Management Journal 50, 25-32.

Elsbach, K.D., Kramer, R.M., 1996. Members’ responses to organizational identity threats: encountering and countering the Business Week rankings. Administrative Science Quarterly 41, 442-76.

Elsbach, K.D., Kramer, R.M., 2003. Assessing creativity in Hollywood pitch meetings: evidence for a dualprocess model of creativity judgments. Academy of Management Journal 46, 283-301 
Etzkowitz, H., 1983. Entrepreneurial scientists and entrepreneurial universities in American academic science. Minerva 21, 198-233.

Etzkowitz, H., 2002. Incubation of incubators: innovation as a triple helix of university-industry-government networks. Science and Public Policy 29(2), 115-28.

Etzkowitz, H., 2003. Innovation in innovation: the Triple Helix of university-industry-government relations. Social Science Information 42, 293-337.

Etzkowitz, H., Leydesdorff, L., 1997. Universities and the Global Knowledge Economy: A Triple Helix of University-Industry-Government Relations. Pinter, London.

Etzkowitz, H., Leydesdorff, L., 2000. The dynamics of innovation: from National Systems and 'Mode 2' to a Triple Helix of university-industry-government relations. Research Policy 29, 109-23.

Fagerberg, J., Landstrom, H., Martin, B.R., 2012. Exploring the emerging knowledge base of 'the knowledge society’. Research Policy 41, 1121-31.

Feldman, M.P., Francis, J., 2003. Fortune favours the prepared region: the case of entrepreneurship and the Capitol Region Biotechnology Cluster. European Planning Studies 11, 765-88.

Feller, I., 1990. University patent and technology-licensing strategies. Educational Policy 4, 327-40.

Ferlie, E., Fitzgerald, L., Wood, M., Hawkins, C., 2005. The nonspread of innovations: the mediating role of professionals. Academy of Management Journal 48, 117-34.

Friedman, J., Silberman, J., 2003. University technology transfer: do incentives, management, and location matter? Journal of Technology Transfer 28, 17-30.

Gardner, W.L., Avolio, B.J., 1998. The charismatic relationship: a dramaturgical perspective. Academy of Management Review 23(1), 32-58.

George, E., Chattopadhyay, P., 2005. One foot in each camp: the dual identification of contract workers. Administrative Science Quarterly 50, 68-99.

Gioia, D., Schultz, M., Corley, K.G., 2000. Organizational identity, image, and adaptive instability. Academy of Management Review 25(1), 63-81.

Glynn, M., Barr, P., Dacin, M., 2000. Pluralism and the problem of variety. Academy of Management Review $25,726-34$.

Glynn, M.A., Navis, C., 2013. Categories, identities, and cultural classification: moving beyond a model of categorical constraint. Journal of Management Studies 50, 1124-37. 
Göktepe-Hultén, D., 2008. Academic inventors and research groups: entrepreneurial cultures at universities. Science and Public Policy 35, 657-66.

Goldfarb, B., Henrekson, M., 2003. Bottom-up versus top-down policies towards the commercialization of university intellectual property. Research Policy 32, 639-58.

Gomez-Mejia, L.R., Balkin, D.B., 1992. Determinants of faculty pay: an agency theory perspective. Academy of Management Journal 35, 921-55.

Goodrick, E., Reay, T., 2010. Florence Nightingale endures: legitimizing a new professional role identity. Journal of Management Studies 47, 55-84.

Haeussler, C., Colyvas, J.A., 2011. Breaking the Ivory Tower: academic entrepreneurship in the life sciences in UK and Germany. Research Policy 40, 41-54.

Hambrick, D.C., Chen, M.J., 2008. New academic fields as admittance-seeking social movements: the case of strategic management. Academy of Management Review 33, 32-54.

Hinings, B., Greenwood, R., 1988. The normative prescription of organizations, in Zucker, L.G. (Ed), Institutional Patterns and Organizations, Culture and Environment. Ballinger, Cambridge, MA, pp. 53-70.

Hsu, G., Hannan, M.T.,(2005. Identities, genres, and organizational forms. Organization Science 16(5), 474-90.

Huang, K.G., Murray, F.E., 2009. Does patent strategy shape the long-term supply of public knowledge? Evidence from human genetics. Academy of Management Journal 52, 1193-221.

Hunt, C.S., Aldrich, H.E., 1996. Why Even Rodney Dangerfield Has a Home Page: Legitimizing the World Wide Web as a Medium for Commercial Endeavors. Paper presented at the annual meeting of the Academy of Management, Cincinnati, $\mathrm{OH}$.

Jain, S., George, G., 2007. Technology transfer offices as institutional entrepreneurs: the case of Wisconsin Alumni Research Foundation and human embryonic stem cells. Industrial and Corporate Change 16, 53567.

Jain, S., George, G., Maltarich, M., 2009. Academics or entrepreneurs? Investigating role identity modification of university scientists involved in commercialization activity. Research Policy 38, 922-35.

Jarzabkowski, P., Fenton, E., 2006. Strategizing and organizing in pluralistic contexts. Long Range Planning 39 , 631-48.

Jensen, M.C., Meckling, W.H., 1976.Theory of the firm: managerial behavior, agency costs and ownership structure. Journal of Financial Economics 3(4), 305-60. 
Jensen, R.A., Thursby, J.G., Thursby, M.C., 2003. Disclosure and licensing of university inventions: 'The best we can do with the s**t we get to work with'. International Journal of Industrial Organization 21, 1271300.

Jepperson, R., 1991. Institutions, institutional effects and institutionalism, in Powell, W.W., DiMaggio, P.J. (Eds), The New Institutionalism in Organizational Analysis. University of Chicago University Press, Chicago, pp. 143-63.

Jung, H.J., Lee, J.J., 2014. The impacts of science and technology policy interventions on university research: evidence from the U.S. National Nanotechnology Initiative. Research Policy 43, 74-91.

Kenney, M., Goe, W.R., 2004. The role of social embeddedness in professorial entrepreneurship: a comparison of electrical engineering and computer science at UC Berkeley and Stanford. Research Policy 33, 691-707.

Kistruck, G.M.; Sutter, C.J.; Lount Jr., R.B.; Smith, B.R., 2013. Mitigating principal-agent problems in base-ofthe-pyramid markets: an identity spillover perspective. Academy of Management Journal 56, 659-82.

Kraatz, M., Block, E., 2008. Organizational implications of institutional pluralism, in Greenwood, R., Oliver, C., Sahlin, K., Suddaby, R. (Eds), The Sage Handbook of Organizational Institutionalism. Sage, Los Angeles, pp. 243-75.

Kreiner, G.E., Hollensbe, E.C., Sheep, M.L., 2009. Balancing borders and bridges: negotiating the work-home interface via boundary work tactics. Academy of Management Journal 52, 704-30.

Lam, A., 2010. From 'ivory tower traditionalists' to 'entrepreneurial scientists'? Academic scientists in fuzzy university industry boundaries. Social Studies of Science 40, 307-40.

Latour, B., Woolgar, S., 1979. Laboratory life: the social construction of scientific facts. Sage, Beverly Hills.

Link, A.N., Siegel, D.S., Bozeman, B., 2007. An empirical analysis of the propensity of academics to engage in informal university technology transfer. Industrial and Corporate Change 16, 641-55.

Link, A., Siegel, N., Donald, S., 2005. University-based technology initiatives: quantitative and qualitative evidence. Research Policy 34, 253-7.

Livengood, R.S., Reger, R.K. 2010. That's our turf! Identity domains and competitive dynamics. Academy of Management Review 35(1), 48-66.

Lockett, A., Wright, M., 2005. Resources, capabilities, risk capital and the creation of university spin-out companies. Research Policy 34, 1043-57.

Louis, K.S., Blumenthal, D., Gluck, M.E., Stoto, M.A., 1989. Entrepreneurs in academe: an exploration of behaviors among life scientists. Administrative Science Quarterly 34, 110-131 
Lounsbury, M., Glynn, M.A., 2001. Cultural entrepreneurship: stories, legitimacy, and the acquisition of resources. Strategic Management Journal 22, 545-64.

Mangematin, V., Cunningham., O'Reilly, P., 2014. PIs as boundary spanners, science and market shapers. Journal of Technology Transfer 39, 1-10.

Markman, G.D., Gianiodis, P., Phan, P., 2009. Supply-side innovation and technology commercialization. Journal of Management Studies 46, 625-49.

Markman, G.D., Gianiodis, P.T., Phan, P.H. Balkin, D.B., 2005. Innovation speed: transferring university technology to market. Research Policy 34, 1058-75.

Markman, G.D., Siegel, D.S. Wright, M., 2008. Research and technology commercialization. Journal of Management Studies 45, 1401-23.

Martin, B., 2012. Are universities and university research under threat? Towards an evolutionary model of university speciation. Cambridge Journal of Economics 36, 543-565.

McNamara, G., Deephouse, D.L., Luce, R.A., 2003. Competitive positioning within and across a strategic group structure: the performance of core, secondary, and solitary firms. Strategic Management Journal 24(2), $161-81$.

Merton, R., 1957. Priorities in scientific discovery. American Sociological Review 22(6), 635-59.

Merton, R.K., 1973. The Sociology of Science. Theoretical and Empirical Investigations. University of Chicago Press, Chicago.

Miles, M.B., Huberman, A.M. 1994. Qualitative Data Analysis: An Expanded Sourcebook. Sage, Thousand Oaks, CA.

Mowery, D.C., Ziedonis, A.A., 2002. Academic patent quality and quantity before and after the Bayh-Dole act in the United States. Research Policy 31, 399-418.

Murray, F., 2010. The Oncomouse that roared: hybrid exchange strategies as a source of distinction at the boundary of overlapping institutions. American Journal of Sociology 116, 348-88.

Muscio, A., 2010. What drives the university use of technology transfer offices? Evidence from Italy. The Journal of Technology Transfer 35(2), 181-202.

Mustar, P., Renault, M., Colombo, M.G., Piva, E., Fontes, M., Lockett, A., Wright, M., Clarysse, B., Moray, N., 2006. Conceptualizing the heterogeneity of research-based spin-offs: a multi-dimensional taxonomy. Research Policy 35, 289-308. 
Mustar, P., Wright, M., 2010. Convergence or path dependency in policies to foster the creation of university spin-off firms? A comparison of France and the United Kingdom. The Journal of Technology Transfer 35, $42-65$.

Navis, C., Glynn, M., 2010. How new market categories emerge: temporal dynamics of legitimacy, identity, and entrepreneurship in satellite radio, 1990-2005. Administrative Science Quarterly 55, 439-71.

Navis, C., Glynn, M., 2011. Legitimate distinctiveness and the entrepreneurial identity: influence on investor judgments of new venture plausibility. Academy of Management Review 36, 479-99.

Nelson, R.R., 1959. The simple economics of basic scientific research. Journal of Political Economy 67(3), 297306.

Nelson, R.R., 2004. The market economy, and the scientific commons. Research Policy 33(3), 455-71.

O'Donoghue, T., Punch K., 2003. Qualitative Educational Research in Action: Doing and Reflecting. Routledge, London.

Oliver, C., 1991. Strategic responses to institutional processes. Academy of Management Review 16, 145-79.

O'Shea, R.P., Allen, T.J., Chevalier, A., Roche, F., 2005. Entrepreneurial orientation, technology transfer and spinoff performance of US universities. Research Policy 34, 994-1009.

O'Shea, R.P., Allen, T.J., O'Gorman, C., Roche, F., 2007. Delineating the anatomy of an entrepreneurial university: the MIT experience. R \& D Management 37, 1-16.

Pfeffer, J., Salancik, G., 1978. The External Control of Organizations. Harper Row, New York.

Phan, P., Siegel, D.S., 2006. The effectiveness of university technology transfer: lessons learned, managerial and policy implications, and the road forward. Foundations and Trends in Entrepreneurship 2(2), 77-144.

Powers, J.B., McDougall, P., 2005. University start-up formation and technology licensing with firms that go public: a resource-based view of academic entrepreneurship. Journal of Business Venturing 20(3), 291311.

Pratt, M.G., 2000. The good, the bad, and the ambivalent: managing identification among Amway distributors. Administrative Science Quarterly 45, 456-93.

Pratt, M.G., Foreman, P.O., 2000. Classifying managerial responses to multiple organizational identities. Academy of Management Review 25(1), 18-42.

Pratt, M.G., Rafaeli, A., 1997. Organizational dress as a symbol of multilayered social identities. Academy of Management Journal 40, 862-98. 
Rao, H., Davis, G.F., Ward, A., 2000. Embeddedness, social identity and mobility: why firms leave the NASDAQ and join the New York Stock Exchange. Administrative Science Quarterly 45(2), 268-92.

Rosa, J.A., Porac, J.F., Runser-Spanjol, J., Saxon, M.S., 1999. Sociocognitive dynamics in a product market. The Journal of Marketing 63, 64-77.

Rasmussen, E., Mosey, S., Wright, M., 2014. The influence of university departments on the evolution of entrepreneurial competencies in spin-off ventures. Research Policy 43, 92-106.

Rothaermel, F.T., Agung, S., Jiang, L., 2007. University entrepreneurship: a taxonomy of the literature. Industrial and Corporate Change 16, 691-791.

Scott, W.R., 1995. Institutions and Organizations. Sage, Thousand Oaks, CA.

Shane, S.A., 2004. Academic Entrepreneurship: University Spinoffs and Wealth Creation. Edward Elgar, Cheltenham.

Siegel, D.S., Waldman, D.A., Atwater, L.E., Link, A.N., 2004. Toward a model of the effective transfer of scientific knowledge from academicians to practitioners: qualitative evidence from the commercialization of university technologies. Journal of Engineering and Technology Management 21, 115-42.

Siegel, D., Waldman, D., Link, A., 2003. Assessing the impact of organizational practices on the relative productivity of university technology transfer offices: an exploratory study. Research Policy 32, 27-48.

Sieger, P., Zellweger, T., Aquino, K.F., 2013. Turning agents into psychological principals: aligning interests of non-owners through psychological ownership. Journal of Management Studies 50(3), 361-88.

Sillince, J.A., Brown, A.D., 2009. Multiple organizational identities and legitimacy: the rhetoric of police websites. Human Relations 62, 1829-56.

Slaughter, S., Leslie, L.L., 1997. Academic Capitalism: Politics, Policies and the Entrepreneurial University. The Johns Hopkins University Press, Baltimore, MA.

Smith, E.B., 2011. Identities as lenses: How organizational identity affects audiences' evaluation of organizational performance. Administrative Science Quarterly 56, 61-94.

Sörlin, S., 2007. Funding diversity: performance-based funding regimes as drivers of differentiation in higher education systems. Higher Education Policy 20, 413-40.

Starr, J.A., MacMillan, I.C., 1990. Resource cooptation via social contracting: resource acquisition strategies for new ventures. Strategic Management Journal 11, 79-92.

Stuart, T.E., Ding, W.W., 2006. When do scientists become entrepreneurs? The social structural antecedents of commercial activity in the academic life sciences. American Journal of Sociology 112, 97-144. 
Stokes, D.E., 1997. Pasteur's Quadrant - Basic Science and Technological Innovation. Brookings Institution Press. Washington, DC.

Strauss, A., Corbin, J., 1998. Basics of Qualitative Research: Techniques and Procedures for Developing Grounded Theory. Sage, Thousand Oaks, CA.

Stryker, S., Burke, P.J., 2000. The past, present, and future of an identity theory. Social Psychology Quarterly $63,284-97$.

Suchman, M., 1995. Managing legitimacy: strategic and institutional approaches. Academy of Management Review 20, 571-611.

Suddaby, R., Greenwood, R., 2005. Rhetorical strategies of legitimacy. Administrative Science Quarterly 50(1), $35-67$.

Swamidass, P.M., Vulasa, V., 2009. Why university inventions rarely produce income? Bottlenecks in university technology transfer. The Journal of Technology Transfer 34, 343-63.

Tartari, V., Salter, A., D’Este, P., 2012. Crossing the Rubicon: exploring the factors that shape academics' perceptions of the barriers to working with industry. Cambridge Journal of Economics 36, 655-77.

Tartari, V., Perkmann, M., Salter, A., 2014. In good company: the influence of peers on industry engagement by academic scientists. Research Policy 23, 1189-203.

Thune, T., Gulbrandsen, M., 2011. Institutionalization of university-industry interaction: an empirical study of the impact of formal structures on collaboration patterns. Science and Public Policy 38, 99-107.

Thursby, G., Thursby, M., 2003. University licensing under Baye-Dohl: what are the issues and evidence? Working paper. http://opensource.mit.edu/papers/Thursby.pdf

Toole, A.A., Czarnitzki, D. 2010. Commercializing science: is there a university brain drain from academic entrepreneurship? Management Science 56, 1599-614.

Turner, J.C., 1987. Rediscovering the Social Group: A Self-Categorization Theory. Blackwell, Oxford.

Van Gestel, N., Hillebrand, B., 2011. Explaining stability and change: the rise and fall of logics in pluralistic fields. Organization Studies 32, 231-52.

Vora, D., Kostova, T. 2007. A model of dual organizational identification in the context of the multinational enterprise. Journal of Organizational Behavior 28, 327-50.

Whetten, D.A., 2006. Albert and Whetten revisited: strengthening the concept of organizational identity. Journal of Management Inquiry 15(3), 219-34.

Yin, R.K., 2009. Case Study Research: Design and Methods, (Vol. 5). Sage, Thousand Oaks CA. 
Zhang, Y., George, J.A., Chan, T.S., 2006. The paradox of dueling identities: the case of local senior executives in MNC subsidiaries. Journal of Management 32, 400-25.

Zimmerman, M., Zeitz, G., 2002. Beyond survival: achieving new venture growth by building legitimacy. Academy of Management Review 27, 414-31.

Zott, C., Huy, Q.N., 2007. How entrepreneurs use symbolic management to acquire resources. Administrative Science Quarterly 52, 70-105.

Zuckerman, E.W., 1999. The categorical imperative: securities analysts and the illegitimacy discount. American Journal of Sociology 104, 1398-438. 


\section{Tables and Figures}

\section{Figure 1: Research framework}

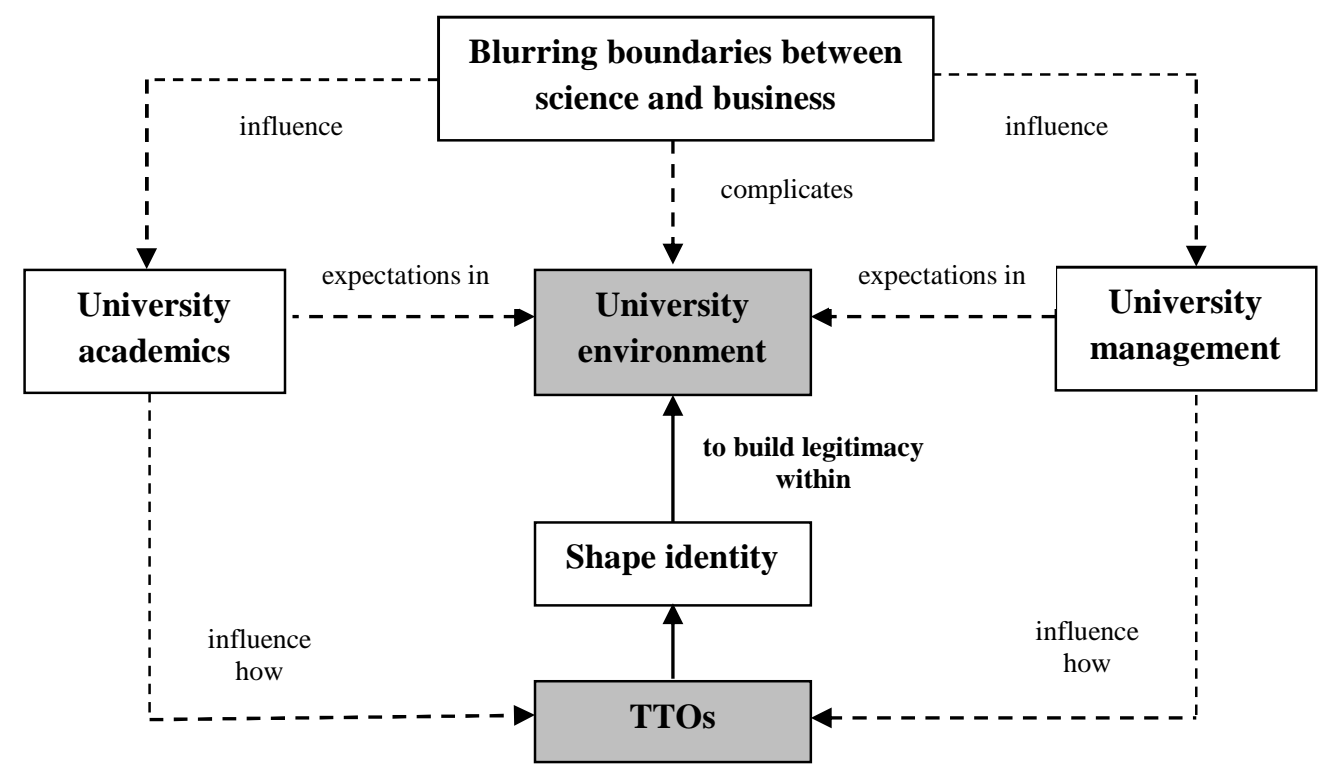

Table 1: Contextual data on participating institutions and TTOs*

\begin{tabular}{|c|c|c|c|c|c|}
\hline \multicolumn{6}{|l|}{ New Zealand } \\
\hline Institution & Ownership & Academics** & TTO Founded & TTO Staff & Respondents \\
\hline NZU1 & Public & 1,500 & 2002 & 9 & 3 \\
\hline NZU2 & Public & 1900 & 1988 & Undisclosed & 2 \\
\hline NZU3 & Public & 1,100 & 2004 & 4 & 2 \\
\hline NZU4 & Public & 800 & 1993 & 11 & 2 \\
\hline NZU5 & Public & 950 & 1997 & 7 & 2 \\
\hline NZU6 & Public & 1050 & 1992 & 6 & 2 \\
\hline NZU7 & Public & 500 & 1994 & 4 & 2 \\
\hline NZU8 & Public & 650 & 1999 & 15 & 2 \\
\hline \multicolumn{6}{|l|}{ Ireland } \\
\hline Institution & Ownership & Academics & TTO Founded & TTO Staff & Respondents \\
\hline IREU9 & Public & 1200 & 2001 & 11 & 5 \\
\hline IREU10 & Public & 900 & 2007 & 11 & 4 \\
\hline IREU11 & Public & 350 & 2007 & 4 & 4 \\
\hline IREU12 & Public & 1300 & 2007 & 6 & 5 \\
\hline IREU13 & Public & 350 & 2007 & 5 & 4 \\
\hline IREU14 & Public & 400 & 2001 & 9 & 5 \\
\hline IREU15 & Public & 450 & 2003 & 8 & 5 \\
\hline \multicolumn{6}{|c|}{ New York (United States) } \\
\hline Institution & Ownership & Academics & TTO Founded & TTO Staff & Respondents \\
\hline USU16 & Private & 300 & 2005 & 8 & 2 \\
\hline USU17 & Private & 3500 & 1982 & 47 & 2 \\
\hline USU18 & Private & 2800 & 1979 & 33 & 2 \\
\hline USU19 & Public & 87,900 & 1979 & 34 & 2 \\
\hline USU20 & Private & 1650 & 1987 & 3 & 2 \\
\hline USU21 & Private & 6650 & 1989 & 11 & 2 \\
\hline USU22 & Private & 1650 & 1981 & 15 & 2 \\
\hline
\end{tabular}


Table 2: Overview of coding process

\begin{tabular}{|c|ccc|}
\hline Coding & $\begin{array}{c}2^{\text {nd }} \text { order } \\
\text { deductive }\end{array}$ & $\begin{array}{c}3^{\text {rd }} \text { order } \\
\text { deductive } \& \text { inductive }\end{array}$ & $\begin{array}{c}4^{\text {th }} \text { order } \\
\text { deductive \& inductive }\end{array}$ \\
\hline Category & 'Identity shaping strategies' & 'Identity type' & 'Identity-legitimacy'
\end{tabular}

$\begin{array}{ccc}\begin{array}{c}\text { Academic } \\ \text { category }\end{array} & \begin{array}{c}\text { Identity-conformance } \\ \text { subcategory (11) }\end{array} & \text { Scientific (18) }\end{array}$

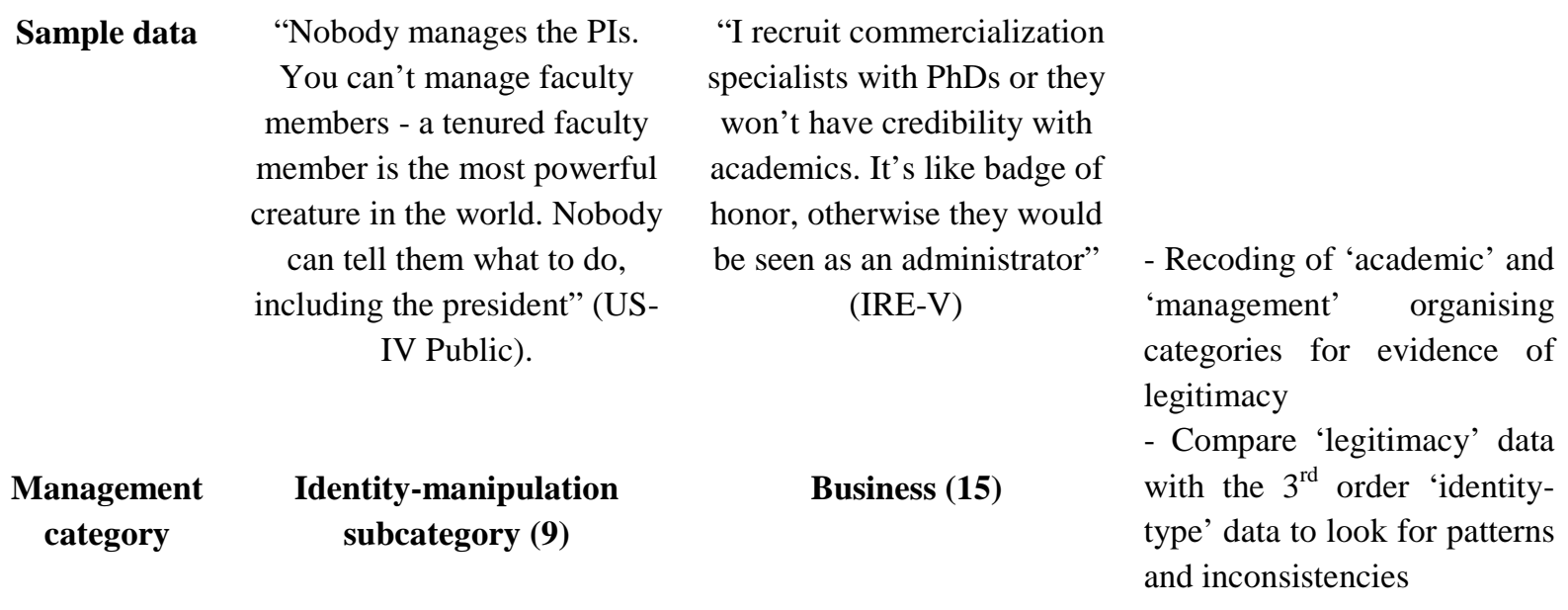

Sample data "The DVC is aware of how important it is for the future of the university. Not just the extra money, it is the contribution of the university to society, government relations and others things - it is just important work coming up with and transferring innovations" (NZ-VI)
"We contribute to the university's core mission when we generate funding from industry that promotes more research taking place and when our technologies lead to patient care benefit"

(US-X Private)

\section{- Recoding of 'academic' and 'management' organising categories for evidence of legitimacy \\ - Compare 'legitimacy' data with the $3^{\text {rd }}$ order 'identity- and inconsistencies}

\section{Table 3: Identity conformance: shaping a scientific identity with university academics}

\footnotetext{
"Having a PhD buys some credibility but at the same time it allows me to be self-depreciating with faculty members from say computer science. I say 'I do have a PhD, I was a faculty member but my knowledge in polymer science does not help me to understand computer security so you'll have to explain it to me from scratch" (US-IV Public)

"I recruit commercialization specialists with $\mathrm{PhDs}$ or they won't have credibility with academics. It's like badge of honor, otherwise they would be seen as an administrator" (IRE-V)

"It is a lot of fun for us is when we can get involved with faculty in a scientific discussion as the people in our office are scientifically quite astute and can really talk to them about what they're doing and try to figure out what the potential is" (US-VII Private)
}

"You got to have a foot in the core academic mission of the university otherwise you will be marginalized...you need to 
make sure that faculty see you as a unit that helps them get their knowledge transferred for the public good" (US-IV Public) "We do need the researcher though to think it has been worthwhile for them to contact this office, and that they understand that we understand and respect their work" (NZ XVI)

"We were out of balance before and too focused on the business side and we alienated the academic side...When it boils down to it we need to secure the supply line, secure good relations with the university as well as the researchers" (NZ-III)

"In order to be successful within an academic environment you need to be within the core business of the university, if you are in the margins nobody pays attention to you. What is a primary mission of any university? It is creation and dissemination of new knowledge. Technology is essentially a subset of knowledge so when you look from that angle technology transfer becomes a part of the core mission of any academic institution" (US-IV Public)

"The way we pick our patent attorneys is not just for writing good patent applications but that they have a really good understanding of the field of research our faculty are in and when we have that conversation, I've seen it more than once when a faculty member comes in being sceptical and says well they're only ten people in the world that can even understand what I'm working on and I know them all - how can an attorney understand it” (US-XII)

\section{Table 4: Identity manipulation: shaping a business identity with university management}

"Our strategy around commercialisation is about reputation, research income and then finally revenue streams - those are the 3 R's. We developed that strategic view and took it the whole way to the council who signed off on them as important aspects for the university. They now guide everything we do" (NZ-XII)

"A few decades ago academic institutions in America were not as heavily relied upon to help the US or a region to stay openly competitive but the world has changed. American higher education like this great research university has something that other countries cannot easily duplicate so the focus is on leveraging our research to help the US or a region stay competitive" (US-II Private)

"Our role is to transfer as much of the university research as possible, whether that is for wealth creation or social benefits it doesn't matter - in doing that the university's reputation for being a valuable member of the community and for bringing value to the research funders is enhanced" (NZ-IX)

"Without demonstrating how the university can benefit from participating in tech transfer it would be ridiculous to think that they would support it. How the university looks for return is not necessarily on monetary terms alone, they're looking at how we're contributing to the society and to the community" (US-II Private)

"We contribute to the university's core mission when we generate funding from industry that promotes more research taking place and when our technologies lead to patient care benefit" (US-X Private)

"Our main goal around commercialization is the reputation of the university. It is not necessarily about generating funds because I think if you get the reputation then the rest handles itself. You get more high quality researchers wanting to be there and they attract top postgraduate students and then industry wants a part of that so they bring in the money" (NZ-XII)

"I know the Vice-Chancellor is very proud of us and he earns a lot of credit internationally when talking about us" (NZ-I) 
Table 5: Summary of research findings

TTO

Perceived determinants of legitimacy

- Understanding and reacting to academic communities" science

\section{University management}

Evidence of added value

- Strategic planning and analysis

- Contributing to strategic purpose and direction of the university

$\begin{array}{ll}\text { Legitimacy-building strategy } & \text { Identity conformance } \\ \begin{array}{l}\text { Type of identity shaped } \\ \text { Details }\end{array} & \begin{array}{c}\text { Scientific } \\ \end{array} \\ & \text { - Prioritise fit with academic norms } \\ & \text { - Publicise academic credentials } \\ & \text { Prioritise visibility, trust, } \\ & \text { relationships and transparency }\end{array}$

Details
Underestimating business expertise

- Intervening

- Avoidance

- Taken for granted
Identity manipulation

\section{Business}

- Publicise intentions and capacity to promote entrepreneurship, diversify revenue streams, and to improve industry connectivity, regional competiveness and the university's reputation and attractiveness to students and research staff

\section{Inadequate championing}

- Inconsistent support

- Rhetoric versus formal support

Figure 2: The relationship between TTO legitimacy and identity-shaping strategies

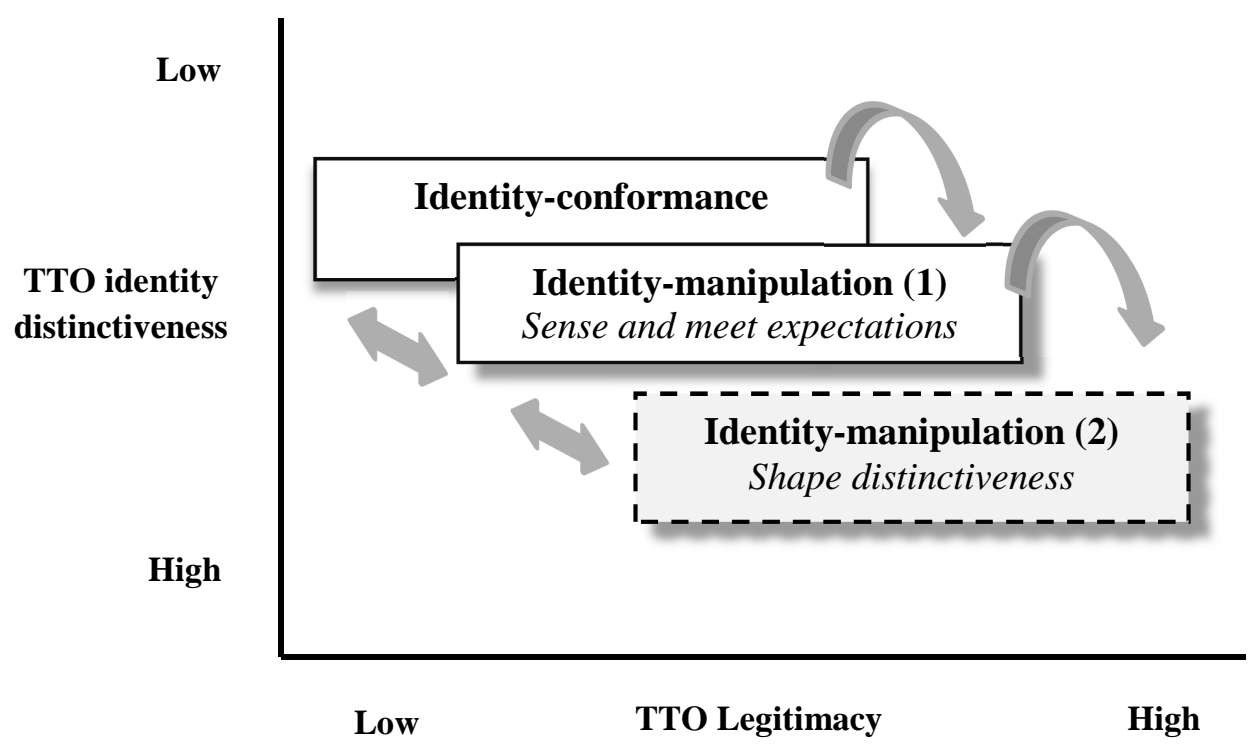

